\title{
The Role of the Gut Microbiota in the Pathogenesis of Diabetes
}

\author{
Weronika Bielka, Agnieszka Przezak and Andrzej Pawlik *(D) \\ Department of Physiology, Pomeranian Medical University in Szczecin, 70-111 Szczecin, Poland; \\ weronika.bielka@wp.pl (W.B.); agn-prze@wp.pl (A.P.) \\ * Correspondence: pawand@poczta.onet.pl
}

Citation: Bielka, W.; Przezak, A.; Pawlik, A. The Role of the Gut

Microbiota in the Pathogenesis of

Diabetes. Int. J. Mol. Sci. 2022, 23, 480

https://doi.org/10.3390/

ijms23010480

Academic Editor: Shin Takasawa

Received: 3 December 2021

Accepted: 29 December 2021

Published: 1 January 2022

Publisher's Note: MDPI stays neutral with regard to jurisdictional claims in published maps and institutional affiliations.

Copyright: (C) 2022 by the authors. Licensee MDPI, Basel, Switzerland. This article is an open access article distributed under the terms and conditions of the Creative Commons Attribution (CC BY) license (https:// creativecommons.org/licenses/by/ $4.0 /)$.

\begin{abstract}
Diabetes mellitus is a significant clinical and therapeutic problem because it can lead to serious long-term complications. Its pathogenesis is not fully understood, but there are indications that dysbiosis can play a role in the development of diabetes, or that it appears during the course of the disease. Changes in microbiota composition are observed in both type 1 diabetes (T1D) and type 2 diabetes (T2D) patients. These modifications are associated with pro-inflammation, increased intestinal permeability, endotoxemia, impaired $\beta$-cell function and development of insulin resistance. This review summarizes the role of the gut microbiota in healthy individuals and the changes in bacterial composition that can be associated with T1D or T2D. It also presents new developments in diabetes therapy based on influencing the gut microbiota as a promising method to alter the course of diabetes. Moreover, it highlights the lacking data and suggests future directions needed to prove the causal relationship between dysbiosis and diabetes, both T1D and T2D.
\end{abstract}

Keywords: diabetes; microbiota; therapy

\section{Introduction}

Diabetes is a group of metabolic diseases characterized by hyperglycemia caused by the direct or indirect deficiency of insulin. Type 1 diabetes (T1D) is an autoimmune disease in which antibodies are produced against various elements of pancreatic $\beta$-cells; the islets producing insulin become deteriorated and, eventually, are completely destroyed, which causes a lack of insulin [1]. Type 2 diabetes (T2D) is triggered by insulin resistance (IR), which leads to an increased demand of peripheral tissues for insulin and, as a consequence, causes the functional failure of $\beta$-cells [2]. Inadequate metabolic management of diabetes can lead to serious long-term complications, including retinopathy, chronic kidney disease, neuropathy and cardiovascular disease, and increased mortality [3-5]. In 2019, the International Diabetes Federation reported that the number of people with diabetes was estimated to be 463 million and would increase to 700 million by 2045 [6]. This great number of people who are at the risk of diabetes, indicates the need to search for further explanations for diabetes pathogenesis, which, as a consequence, can lead to the development of new strategies aimed at preventing the disease or alleviating its course.

The gut microbiota contribute to the proper functioning of human organisms [7]. They create a dynamic ecosystem that is modulated by internal and external factors. Altered composition of intestinal bacteria can participate in the pathogenesis of disorders, such as obesity, diabetes and heart failure [8-10], the prevalence of which is still increasing in the world. Thus, it is of great importance to discover whether the bacteria contribute to the development of these diseases of civilization. It can not only help to modify their course or to delay the appearance of complications, but also to prevent the onset of the disorders. In this review, we describe the differences in the gut microbiota in patients with T1D and T2D in comparison to healthy individuals, explain the probable impact of altered bacterial composition on the host organism and indicate potential therapeutic targets aimed at the microbiota, which can influence the course of diabetes. Moreover, we focus on lacking data in the area concerning the gut microbiota, point out the weak points of studies conducted so 
far and suggest future directions needed to prove the causal relationship between dysbiosis and diabetes, both T1D and T2D.

\section{The Gut Microbiota-Role in Host Homeostasis}

The term "the gut microbiota" refers to more than $10^{14}$ bacteria that settle in the gastrointestinal tract, in which they perform a variety of functions, not all yet fully understood. The "microbiome" is considered as the genome of the whole microbiota. The number of bacterial cells was estimated to be about 10 times higher than the number of human cells [11], but nowadays it is known that the numbers of bacterial and human cells are similar [12]. The microbiota of healthy adults consist of six phyla-Firmicutes and Bacteroidetes, which are the major groups of bacteria, but also Proteobacteria, Actinobacteria, Fusobacteria and Verrucomicrobia. The microbiota of adults include a wide range of species (about 500-1000) belonging to two main phyla-Firmicutes and Bacteroidetes-which makes the bacterial community in every individual specific and unique $[13,14]$. Maintaining this diversity and tight homeostasis between bacteria is supposed to be essential to keep human health in good condition, and dysbiosis can contribute to the development of metabolic diseases, such as obesity or diabetes $[8,15,16]$.

The intestinal microbiota contribute to carbohydrate metabolism by hydrolyzing and fermenting polysaccharides delivered with food. As a consequence, monosaccharides and short-chain fatty acids (SCFAs) are produced, which can influence the colon locally, but can also be absorbed by the host into the circulation and influence the metabolism of different organs [17]. SCFAs, consisting predominantly of acetate, propionate and butyrate, act through G protein-coupled receptors-GPR41, GPR43, and GPR109A—and histone deacetylase [18-22]. These receptors are expressed in various tissues; for instance, adipose tissue, distal ileum, colon, lymph nodes and immune cells-neutrophiles and monocytes [19-21]. Bacteroidetes mainly generate acetate and propionate, and Firmicutes produce butyrate [23]. Species of the genus Bifidobacterium, belonging to Actinobacteria, directly produce a great amount of the SCFA acetate, but they also produce lactate, which is metabolized by other bacteria to butyrate [24,25]. SCFAs regulate the proper function, motility and integrity of the gastrointestinal tract. They probably improve glucose homeostasis and strengthen satiety by increasing the production of the glucagon-like peptide-1 (GLP-1) in the intestine [26]. They influence insulin sensitivity and glucose tolerance by mediating the glycemic response, help to maintain the integrity of the gut epithelium via inducing mucin synthesis and improve the intestinal barrier by facilitating tight junction assembly [27,28]. They can also lead to the increased secretion of peptide YY and leptin, affecting satiety [29]. Moreover, SCFAs support the host immune system, influencing the functions of macrophages, dendritic cells, T cells and B cells, and, as a consequence, prevent the invasion of pathogens, such as Shigella and entero-hemorrhagic Escherichia coli [24,30-32]. The gut microbiota are crucial for proper intestinal barrier functioning. They provide adequate energy for the proliferation of epithelial cells, as butyrate is the main energy source for colonocytes, as well as stimulating the immune system to properly respond to pathogens [33-35]. Actinobacteria contribute to the maintenance of intestinal barrier homeostasis [36].

The gut microbiota are able to synthesize branched-chain amino acids (BCAAs)—leucine, isoleucine and valine [37]. These molecules can be considered as indicators of IR and predictors of diabetes mellitus development, because the serum metabolomes of patients suffering from IR or T2D contain an increased amount of BCAAs [38,39]. It has been proved that the main species positively associated with IR are Prevotella copri and Bacteroides vulgatus. In turn, the leading species negatively associated with IR are Butyrivibrio crossotus and Eubacterium siraeum [38]. The increased intake of BCAAs in food is associated with a higher risk of IR appearance, and decreased consumption can cause an improvement of postprandial insulin sensitivity $[40,41]$.

The primary bile acids (Bas) are synthesized from cholesterol in the liver and secreted with bile into the gut lumen. Further, they are metabolized by the microbiota to secondary 
Bas and mostly reabsorbed into circulation, influencing different host processes [42]. Their main role is the participation in the process of digestion and absorption of lipids and vitamins soluble in lipids. They contribute to the proper regulation of carbohydrate and lipid metabolism, as well as to the regulation of energy expenditure via the farnesoid $X$ receptor (FXR) and TGR5 [42,43]. Depending on the localization of activation of FXR (in the intestine or in the liver), they can show features that are either protective from or conductive to steatosis and obesity [44-46]. Moreover, these receptors play a role in the production and release of GLP-1 by L cells $[47,48]$. The microbiota not only produce secondary BAs, but also regulate their uptake and participate in the synthesis of primary BAs by regulating the crucial enzymes [49].

The gut microbiota play a crucial role in preventing infectious diseases by occupying host niches, which can make the host resistant to colonization by pathogens [50].

The gut microbiota also participate in the proper functions of the immune system, which is a complicated mechanism consisting of a variety of different actions. For instance, they take part in the process of inflammatory cytokine production or stimulate the proliferation of group 3 innate lymphoid cells in the colon [51,52]. Moreover, they affect CD8+ T cell memory and macrophages through one of the SCFAs, butyrate [53,54]. The gut microbiota also synthesize and metabolize vitamin $\mathrm{K}$ and $\mathrm{B}$ group vitamins, as well as metabolizing drugs and toxins [55].

Bacteria belonging to the phyla Proteobacteria and Actinobacteria are less abundant than Firmicutes and Bacteroidetes [56]. A temporary dominance of Proteobacteria, especially Enterobacteriaceae, has been found in newborn mice [57]. By consuming oxygen and altering the $\mathrm{pH}$, Proteobacteria species, facultative anaerobes, play a key role in preparing the suitable habitat of the infant gut for colonization by strict anaerobes [58]. Vaughn et al. have shown that mice fed with a high-fat diet are characterized by microbiota changes, especially an increase in the level of Proteobacteria, which are probably directly associated with the reorganization of vagal afferents and microglia activation in the nucleus of the solitary tract [59]. A short summary of the role of the gut microbiota is presented in Figure 1.

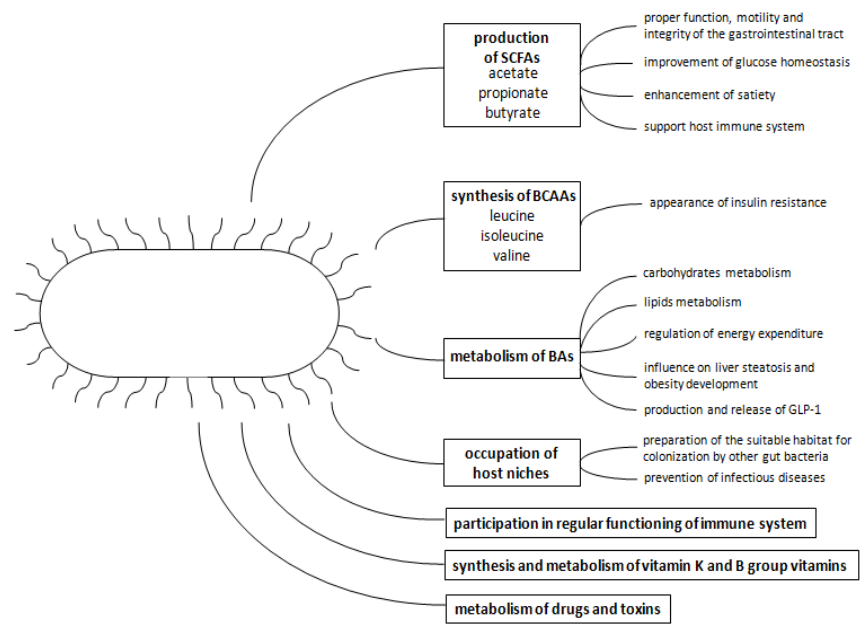

Figure 1. The role of the gut microbiota in maintaining host homeostasis.

\section{Changes in the Composition of the Gut Microbiota in Patients with T1D}

The stability, connectivity, abundance and composition of the intestinal microbiota are probably associated with the development of T1D [60]. Several studies have provided information about an altered gut microbiota in T1D-affected patients. Giongo et al. indicated that a high Firmicutes / Bacteroidetes ratio and the instability of the microbiota can be one of the early diagnostic markers of developing autoimmune disorders, such as T1D [61]. De Goffau et al. examined the composition of the gut microbiota at the onset of T1D in young children. In diabetic children, there was an increased level of Bacteroidetes and Streptococcus mitis, while in healthy controls there was a higher prevalence of the butyrate 
producers Lactobacillus plantarum and Clostridium clusters IV and XIVa [62]. Similar conclusions were drawn by Mejía-León et al. At diagnosis, T1D-affected patients had a dominance of Bacteroides and controls had a higher level of Prevotella, but after 2 years of treatment with insulin, the gut microbiota of patients and of controls were similar [63]. The fecal microbiota in early-onset T1D were also analyzed by metagenomic sequencing in the TEDDY longitudinal study. Vatanen et al. indicated that in stool samples from children diagnosed with T1D, the levels of Roseburia hominis, Alistipes shahii and Bifidobacterium pseudocatenulatum were higher, whereas in controls without T1D, levels of Lactococcus lactis and Streptococcus thermophilus were raised. The control group of children not only had more species common in dairy products, but also their microbiota consisted of more genera associated with the biosynthesis of SCFAs and fermentation. This finding supports the theory of the protective effects of SCFAs in T1D [64]. Pellegrini et al. showed a characteristic inflammatory profile and microbiota in the duodenal mucosa of patients with T1D. In the samples of mucosa, increased inflammation and monocyte/macrophage lineage infiltration were observed. In patients with T1D, the level of Firmicutes and the Firmicutes/Bacteroidetes ratio were raised and the levels of Proteobacteria and Bacteroidetes were reduced [65]. Moreover, in the study of Siljander et al., the pro-inflammatory environment in the gut in children developing T1D was related to a decreased level of Firmicutes and increased amount of Bacteroidetes [66]. Dissimilar conclusions between studies can result from the distinct methods used in the research, but also from the differences in the gut microbiota between individuals as a consequence of their geographical location [67]. A short comparison of these changes in the gut microbiota in individuals with diabetes is presented in Table 1.

Table 1. A comparison of changes in the gut microbiota occurring in individuals with type 1 diabetes or type 2 diabetes in comparison to healthy individuals. A description is given in the text above. $\uparrow$-increased level, $\downarrow$-decreased level.

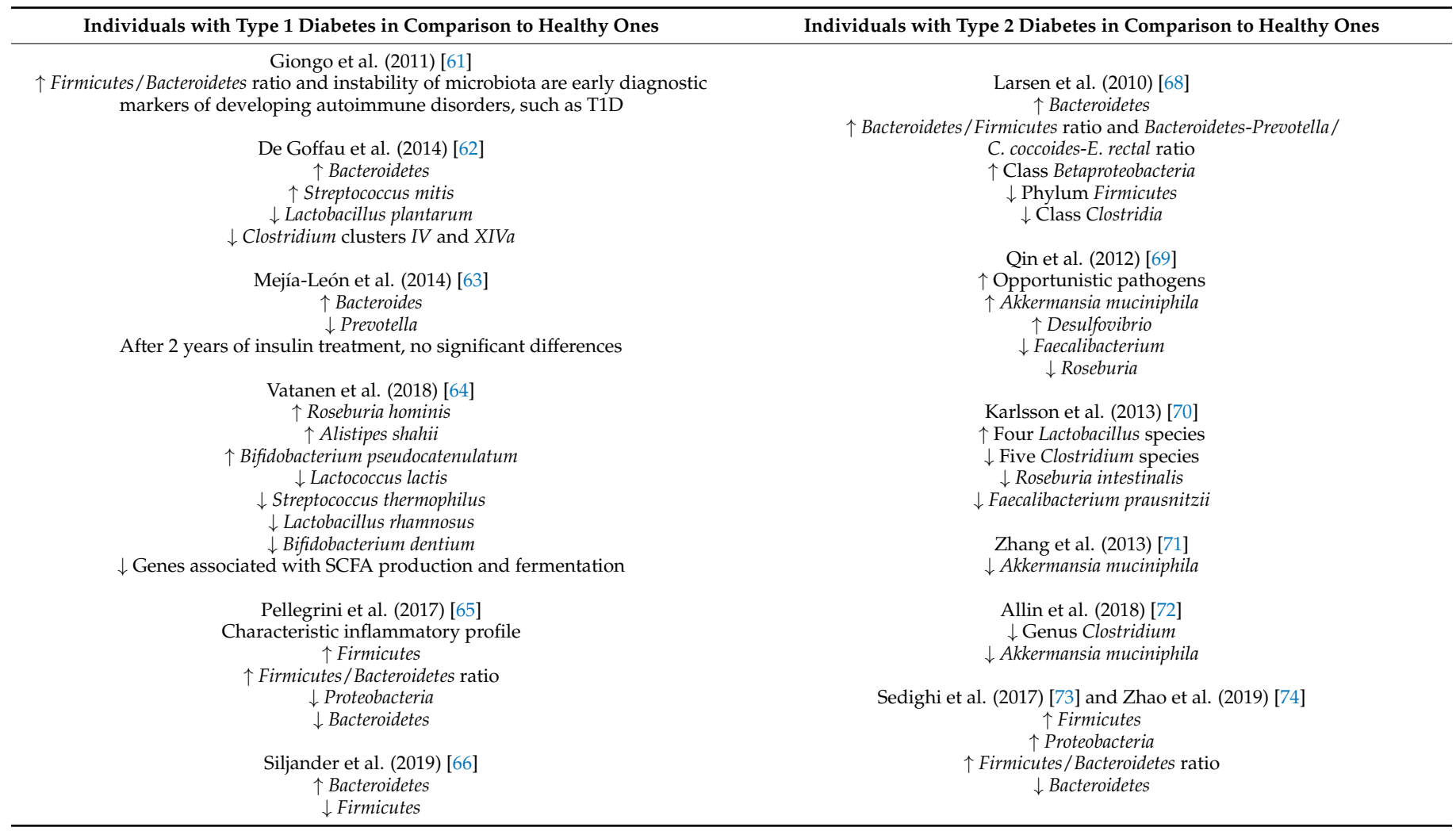

\section{The Potential Role of the Gut Microbiota in the Development of T1D}

T1D is defined as a $\beta$-cell-mediated pro-inflammatory state, induced by both innate and adaptive immunity [75]. Specific human leucocyte antigen (HLA) genotypes, such as 
DQ2, DQ8, DR3 and some DR4 alleles, are the main factors of a genetic predisposition to T1D development [76]. However, in family and twin studies, it has been proved that only $20-30 \%$ of genetically predisposed individuals carrying these alleles will develop T1D [77]. In disease onset, equally important is the impact of environmental factors, such as the way of feeding, diet or exposure to viruses in early childhood [78]. Furthermore, altered gut bacterial composition can be associated with the pathogenesis of insulin dysfunction and T1D [53]. Nevertheless, most studies investigating the concept that gut microbiota affect the pathogenesis of T1D are performed on mouse models, while there are still an insufficient number of human studies to prove it.

During early childhood, such processes occur as the development of the immune system, maturation of the gut microbiota and appearance of the first autoantibodies bound to T1D [65]. Among the factors that can modify the composition of the intestinal microbiota are breastfeeding, nutrition, route of delivery, use of antibiotics and exposure to the microbes in the environment $[79,80]$. Their action can result in intestinal barrier disruption and defective maturation of the immune response, eventually leading to T1D progression later in life [81]. Moreover, the genetic set-up of the host can interact with the intestinal microbiota, causing changes in the microbial composition, activation of immunity and susceptibility to T1D $[82,83]$.

Dysbiosis, defined as the repetitive or prolonged deviation from optimal microbial homeostasis, can cause the loss of self-tolerance and the spread of effector cells and proinflammatory signals in the organism [65]. These processes coincide with the increased permeability of the intestinal wall, translocation of microbial material through the epithelium and enhanced presentation of antigens, as well as autoantigens [65]. This leads to the activation of the pro-inflammatory pathway in the intestine, lymph nodes and pancreas [65]. Furthermore, the exocrine function of the pancreas, quality of the mucosal barrier and adhesion of the microvilli are depleted in patients with T1D [84,85]. Some members of Bifidobacterium, Bacteroides and Ruminococcus can cause mucin degradation and impair the integrity of the mucosal barrier [86]. Intestinal inflammation and the reduction of SCFAs caused by dysbiosis can be crucial to the pathogenesis of T1D [87]. The clinical onset of T1D is probably preceded by heightened gut permeability [88]. An adequate amount of butyrate, produced mainly by Firmicutes, leads to appropriate mucin synthesis and enhances tight junctions in the intestine [89,90]. Butyrate also shows anti-inflammatory properties and decreases bacterial transport through the epithelial cells [91]. A butyrate diet helped to increase the amount and function of regulatory T cells [92], whereas acetate- and butyrate-yielding diets decreased serum concentrations of diabetogenic cytokines, such as IL-21, and enhanced gut integrity. This type of diet allowed a reduction in the incidence of diabetes in NOD (non-obese diabetic) mice. Moreover, female NOD mice had a larger number of pancreatic islets with no infiltration [93].

The alteration of intestinal microbes can induce the leakage of fatty acids and lipopolysaccharides (LPSs) by destroying the intestinal mucosal barrier. This causes the activation of toll-like receptor 4 (TLR4), which results in metabolic inflammation [94]. TLRs are engaged in maturation of dendritic cells and recognizing pathogen-associated molecular patterns derived from microbiota [95]. They contribute to protecting the host from infectious microbes. MyD88 is an adaptor not only for TLRs and interleukin 1, but also other innate immune receptors. A defect of MyD88 can alter the composition of microflora in the distal part of the intestine [92]. Moreover, in NOD mice, the knockout of MyD88 protected against T1D development [93]. LPS is a bacterial endotoxin and one of the components of the outer membrane of Gram-negative bacterial species, and probably acts as a molecular link between gut microbiota, inflammation and T1D [53]. In a case-control study, it was proved that patients with T1D have higher circulating LPS levels than those without diabetes [96]. LPSs can be involved in diabetes development, because they lead to the impairment of pancreatic $\beta$-cell function and increase the level of pro-inflammatory cytokines [97]. In mouse models, an oral injection of $E$. coli LPS improved local immunity, while an intraperitoneal injection of E. coli LPS improved the autoimmune response and decreased the incidence of T1D $[98,99]$. 
However, it is difficult to conclude whether microbial alteration is causal or consequential for T1D development. The possible influence of dysbiosis on T1D development is presented in Figure 2. Most current studies mainly show the involvement of intestinal microbiota in the $\beta$-cell autoimmunity process, and do not focus on an explanation of whether gut microbiota activate T1D. On the one hand, the state of dysbiosis during the maturation of the immune system can destroy self-tolerance and control of the inflammatory response, which can eventually lead to increased susceptibility to immune-mediated diseases, such as T1D. However, on the other hand, pro-inflammatory intestinal dysbiosis and changed microbial diversity can cause T1D activation after seroconversion. How the mechanisms of relatively local intestinal inflammation spread to an autoimmune process of the whole organism is not clear enough [66]. It is necessary to perform new interventional studies and not only observational ones. There exists a strong need to prove the causal relationship between T1D and intestinal microbiota, and the exact mechanisms that participate in the processes described above.

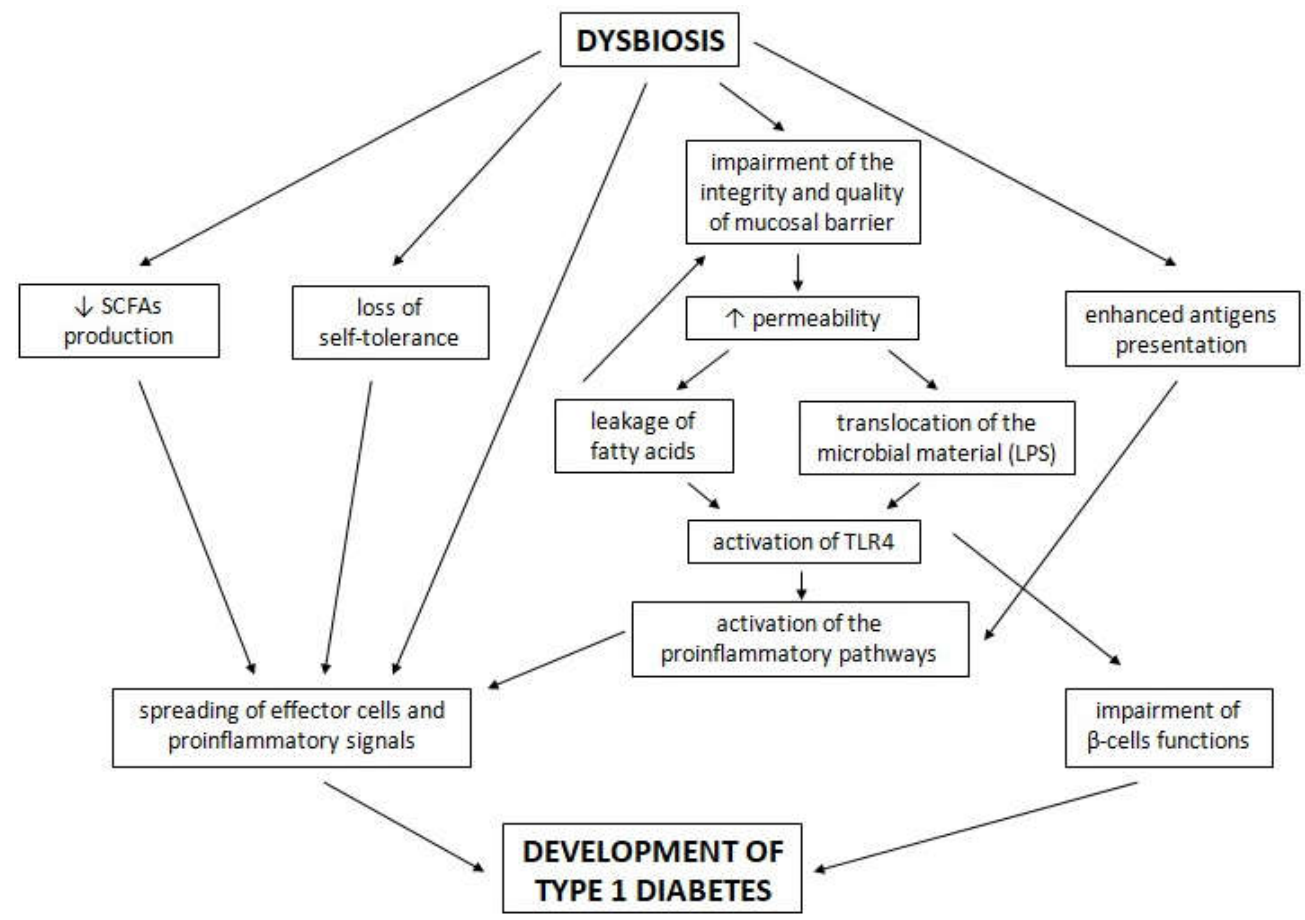

Figure 2. The possible influence of dysbiosis on type 1 diabetes development. A description is given in the text above.

\section{Changes in the Composition of the Gut Microbiota in Patients with T2D}

Similarly to T1D, the microbiota in patients with T2D differ from those occurring in healthy individuals [16]. The main change seen in various research is an increase in the amount of opportunistic pathogens and a decrease in bacteria producing butyrate, one of the SCFAs [97]. One of the first studies on the microbiota of subjects with T2D, conducted by Larsen et al., showed decreased levels of the phylum Firmicutes and class Clostridia. Moreover, the Bacteroidetes / Firmicutes ratio, as well as the Bacteroidetes-Prevotella/C. coccoidesE. rectal ratio, was positively correlated with plasma glucose concentration. Moreover, the class Betaproteobacteria was increased and positively correlated with reduced glucose tolerance $[68,100]$. Qin et al. and Karlsson et al. indicated that the gut microbiota of individuals suffering from T2D are characterized by increased amounts of opportunistic pathogens and decreased levels of Faecalibacterium and Roseburia, butyrate producers [69,70]. Qin et al. also reported an increased level of Akkermansia muciniphila, which shows mucin-degrading properties and plays an important role in gut barrier functions, and the sulphate-reducing species Desulfovibrio [69]. Moreover, Karlsson et al. showed an increased level of four Lactobacillus species and a decreased amount of five Clostridium species [70]. Zhang et al. 
indicated a decreased level of Akkermansia muciniphila in patients with T2D [71]. A similar observation was also made by Allin et al.--in individuals with prediabetes, there are fewer species of the genus Clostridium and Akkermansia muciniphila, in comparison to healthy people [72]. Conversely to Larsen et al., Sedighi et al. indicated a decreased level of Bacteroidetes and increased level of Firmicutes and Proteobacteria, which results in a higher Firmicutes / Bacteroidetes ratio [73]. These conclusions were confirmed later by Zhao et al., but they also elucidated that the enhanced Firmicutes / Bacteroidetes ratio was definitely higher in T2D-affected patients with complications of the disease than in individuals without complications [74].

The results of various studies differ from one another, but, in general, the genera negatively associated with T2D are Bacteroides, Bifidobacterium, Faecalibacterium, Akkermansia and Roseburia, and the genera Fusobacteria, Ruminococcus and Blautia are positively connected with this disease [101]. The inconsistent findings are the results of the inconsistency between studies. The DNA extraction protocols are not comparable between studies, nor are the sampling of specimens and the procedures using bioinformatic methods. Insufficient sample sizes and the interpersonal variation or environmental factors, such as the geographical locations, ages or gender, type of diet and medicaments, can be responsible for the discrepancies. Different methods, for instance microarrays, fluorescence in in situ hybridization or next-generation sequencing, lead to conflicting findings. Early studies were based on rRNA gene amplification by PCR, then on multiple sequence alignment and phylogenetic reconstruction. These studies were limited by the costs and time, which caused a problem in the exact estimation of the abundance of the microbiota corresponding to the sequences [102]. Moreover, research based on rodent microbiomes is more reliable when demonstrating probable mechanisms existing in human biology, rather than identifying exact taxa or species, because mouse microbiota are apparently different from human microbiota. Despite Firmicutes and Bacteroidetes being the dominant phyla, the composition at genus level is utterly different [103]. The protocols should be unified to enable definition of the exact changes of the gut microbiota in patients with T2D.

Bacteroides, belonging to the phylum Bacteroidetes, were negatively associated with T2D in the research [104-106]. Taking into consideration specific species, B. intestinalis, Bacteroides sp. 20_3 and B. vulgatus were decreased in T2D-affected patients [70,107,108]. In obese patients with T2D who had a laparoscopic sleeve gastrectomy and, subsequently, experienced diabetes remission, the level of B. stercoris was increased [109]. In animal studies, the administration of B. acidifaciens and B. uniformis favourably affected the glucose tolerance and IR in diabetic rodents $[110,111]$. Studies indicate a potentially beneficial effect of Bacteroides on glucose metabolism and suggest an explanation for the negative correlation between Bacteroides and T2D.

The genera Roseburia, Faecalibacterium, Lactobacillus, Ruminococcus and Blautia belong to the phylum Firmicutes. Generally, a decrease in the Roseburia level has been found in T2D-affected patients, in comparison to healthy individuals [68,104,108,112]. Considering specific species, $R$. intestinalis was positively and R. inulinivorans and Roseburia_272 were negatively associated with diabetes $[70,108,109]$. Faecalibacterium were found to be decreased in T2D-affected patients, but, at species level, F. prausnitzii was negatively correlated with the disease $[70,108,112,113]$. Lactobacillus species are rather positively associated with T2D, for instance L. acidophilus or L. salivarius, but some species, such as L. amylovorus, are negatively associated with diabetes [70,104,107,114,115].

Species of the genus Bifidobacterium, belonging to Actinobacteria, are strongly negatively associated with T2D [73,104,107,113]. In animal studies, the administration of Bifidobacterium spp. Improved glucose tolerance in diabetic mice, suggesting a protective role of bifidobacterial in T2D [116,117].

A short comparison of these changes in the gut microbiota in individuals with diabetes is presented in Table 1. 


\section{The Potential Role of the Gut Microbiota in the Development of T2D}

The development of T2D is mainly caused by insufficient insulin secretion by $\beta$-cells localized in the pancreas and the state called "insulin resistance", which is the inability of insulin-sensitive tissues to respond to insulin properly [118]. The dysfunction of $\beta$-cells leads to a reduction in insulin secretion, resulting in accelerated glucose plasma levels. IR stimulates the production of glucose in the liver and impairs glucose uptake in the liver, muscle and adipose tissue, which increases glycemia as well. This situation leads to chronic hyperglycemia, affecting various organs and tissues, and resulting in detrimental microand macrovascular complications [119]. Chronic low-grade inflammation contributes to the development of IR and, consequently, of T2D [120]. Risk factors for T2D are genetic predisposition, ethnicity and family history of diabetes, as well as metabolic and environmental factors, such as obesity, low-grade physical activity and diet. The strongest risk factor is obesity, which is connected with metabolic changes leading to IR [121-123].

Much of our understanding of the exact role of the intestinal microbiota is based on studies focused on germ-free animals, which are born and kept without any contact with bacteria and can be exposed to specific microbes in the course of the research. Studies have shown that these rodents are resistant to obesity induced by diet [124,125], and exposure to Enterobacter cloacae, a bacterium linked to obesity, or bacteria received from obese donors leads to the increased capacity for energy harvest, weight gain and impaired glucose tolerance [126-128]. These studies suggest probable causality between the gut microbiota and obesity.

T2D is characterized by the decreased production of butyrate [97], one of the SCFAs that supports proper function of $\beta$-cells in the pancreas, especially after food intake [129]. Butyrate contributes to the modulation of immune system functions and protection against pathogen invasion [130]. It affects the functions of intestinal macrophages and downregulates pro-inflammatory mediators induced by LPSs, for instance IL-6, IL-12 and nitric oxide, as well as promoting regulatory $\mathrm{T}$ cell differentiation [131-133]. It also activates intestinal gluconeogenesis and, as a result, favorably affects glucose homeostasis [134]. Sanna et al. have shown that a host genetic-driven increase in the gut production of butyrate is associated with an improved insulin response following an oral glucose test, and that abnormalities in production or absorption of propionate are causally related to increased risk of T2D [129]. This state leads to low-grade inflammation $[135,136]$. In recent studies, it has been shown that dysbiosis occurring in NOD mice is associated with a reduction in butyrate levels, which leads to increased activity of histone deacetylase 3 (HDAC3), changed colon permeability, increased reactive oxygen species (ROS) production and a rise in IL- $1 \beta$ levels, as well as a decrease in amounts of IL-10 and IL-17 $\alpha$ [137]. Moreover, it has been indicated that butyrate supplementation restores homeostatic levels of the inflammatory markers and reduces ROS production [137]. In an obese/prediabetic mouse model, butyrate intake has been proved to protect against the detrimental effects of high-fat diet, such as weight gain, body adiposity, IR, hyperglycemia and hyperinsulinemia [138].

Moreover, it is suggested that patients who will develop T2D in the future show a reduction in BCAA catabolism, as well as changes in lysophospholipid metabolism and in the BA pool [139]. Additionally, individuals with IR have an enhanced potential for biosynthesis of BCAAs [32]. As mentioned before, an increased BCAA level can be associated with a higher risk of developing IR [38]. Studies suggest that modifications of the BA pool by sequestrants can improve glycemic control in T2D-affected patients, but the mechanisms underlying these changes remain unknown [140].

Similar to T1D, T2D is probably associated with LPSs, which trigger the development of inflammation and IR acting through TLR4 [141,142]. TLR4 belongs to a family of pattern-recognition receptors, toll-like receptors, which contribute to the activation of proinflammatory signaling pathways, and cytokine expression and secretion in the presence of bacterial pathogens $[143,144]$. In vitro and in vivo studies have shown that free fatty acids can influence macrophages and adipocytes through TLR4, inducing inflammation. As a result, they are able to suppress insulin signaling through serine phosphorylation of 
insulin receptor substrate 1 (IRS-1) and influence glucose homeostasis [143,145]. This IRS-1 modification is considered to be a marker of the IR state [146]. It has been indicated that individuals with diabetes are characterized by higher fasting and postprandial concentrations of LPSs, in comparison to non-diabetic individuals, which can be caused by an increased permeability of the intestine and enhanced LPS absorption [141]. Increased circulating LPSs enhance the expression of inducible nitric oxide synthase (iNOS) through the activation of TLR4, which, as a consequence, induces protein S-nitrosation/S-nitrosylation of the insulin receptor, IRS-1 and Akt, and alters their proper functions [147-151]. Moreover, it has been suggested that metabolic endotoxemia dysregulates the inflammatory tone and triggers body weight gain and diabetes [141]. Probably, the gut microbiota have properties to modify this state of inflammation and endotoxemia due to their ability to affect the permeability of the intestine [152,153]. Endotoxemia in obesity and T2D becomes apparent, but there is still a lack of human studies that would show increased intestinal permeability and changed tight junction expression evidently. The possible influence of dysbiosis on T2D development is presented in Figure 3.

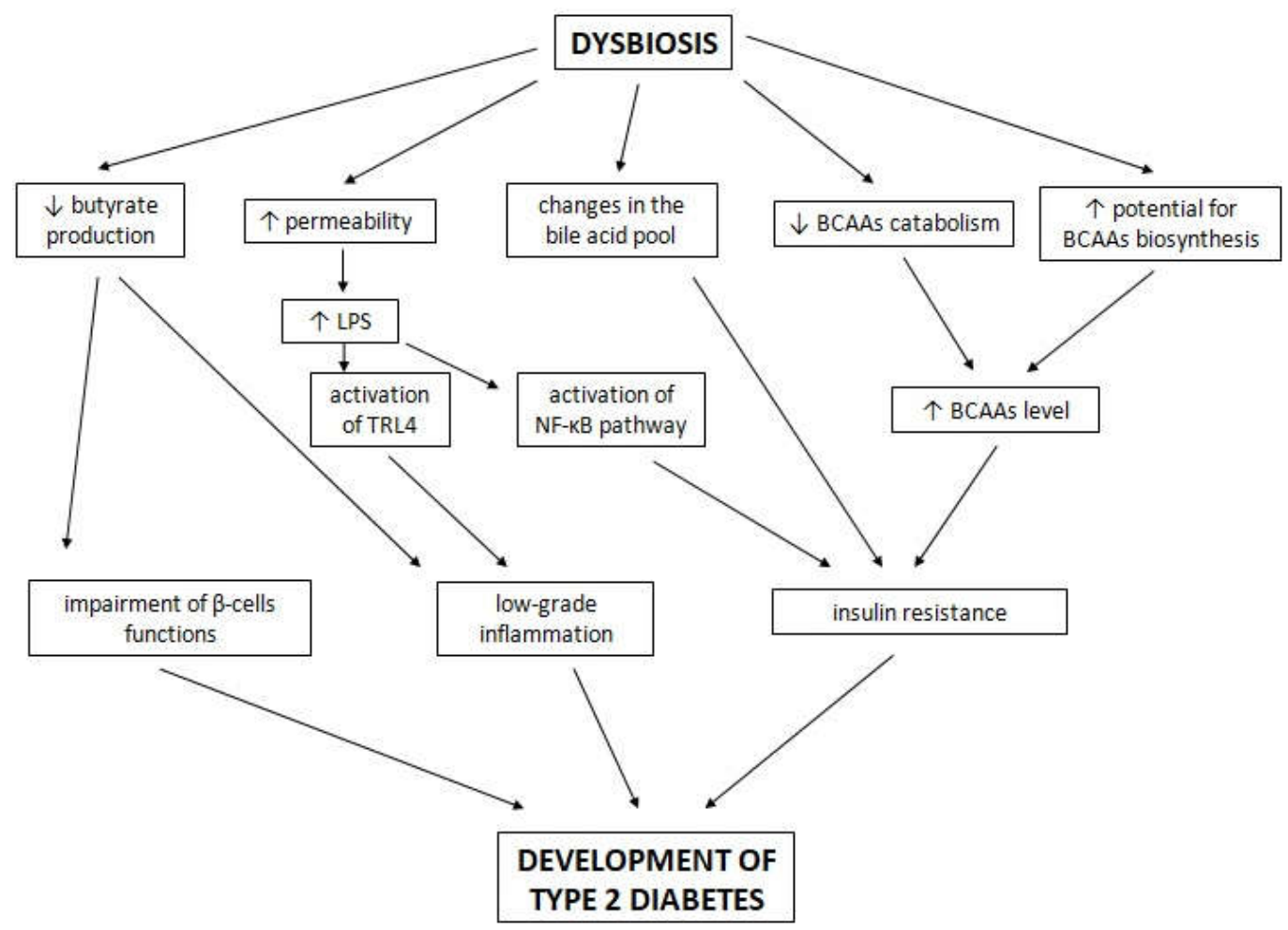

Figure 3. The possible influence of dysbiosis on type 2 diabetes development. A description is given in the text above.

\section{The Role of Roseburia Hominis, Faecalibacterium Prausnitzii and Akkermansia Muciniphila}

The intestinal abundance of Roseburia_272 and Faecalibacterium prausnitzii is lower in T2D-affected individuals than in healthy ones [70,154]. The presence of the strictly anaerobic flagellated bacterium Roseburia hominis, belonging to the phylum Firmicutes, can contribute to the induction of genes involved in the promotion of gut barrier functioning and innate immunity, as well as in the promotion of mucosal T-cell expansion and differentiation of $\mathrm{T}$ cells [155]. Moreover, it is able to penetrate the mucous layer and adhere to the epithelial cells, which enhances its probiotic properties $[156,157]$. Hereby, R. hominis promotes and regulates the immune system.

Faecalibacterium prausnitzii, a representative of the phylum Firmicutes, has been shown to be one of the crucial producers of butyrate $[158,159]$. It is the most abundant bacterium in the intestinal microbiota occurring in healthy individuals [160]. It has proven anti- 
inflammatory properties, as it is able to induce a tolerogenic cytokine profile, decreasing acute, chronic and low-grade inflammation [161-164]. It is also one of the main butyrate producers $[91,161]$. Moreover, $F$. prausnitzii has an ability to produce salicylic acid, which has anti-inflammatory properties through the reduction of IL-8 levels [165]. It also synthesizes a protein called microbial anti-inflammatory molecule (MAM), which has been shown to have positive effects on gut inflammation and epithelial mucosa when supplemented in inflammatory bowel disease [166]. MAM probably regulates tight junction proteins and restores cell permeability, and thus influences the integrity of mucous intestinal cells [167]. It has been proved that the transplantation of $F$. prausnitzii can result in positive effects in the treatment of diabetes and its complications [168].

Akkermansia muciniphila is a bacterium belonging to the phylum Verrucomicrobiota and is responsible for mucin degradation in the gut lining, which, as a result, contributes to the syntropic interactions and stimulation of the metabolite pool in the intestine [169]. Moreover, it stimulates mucin synthesis, probably in an autocatalytic process $[170,171]$. In rodent studies, the colonization of the intestine by A. muciniphila has been shown to exert transcriptional changes manifesting as an increase in the expression of genes connected with immune processes and the metabolism of lipids [172,173].

\section{Preventive and Therapeutic Perspectives including the Gut Microbiota}

Diabetes worsens the quality of life of affected patients, leads to many early and late complications, burdens the health care system by increasing treatment costs and causes prolonged absence from work [174]; therefore, it is of great importance to create methods for alleviating the course of the disease. A promising approach is the modification of the amount and composition of the gut microbiota. A healthy diet and physical activity are among the factors that can influence the gut microbial ecosystem. In active women, in comparison to sedentary ones, an increased abundance of Roseburia hominis, Akkermansia muciniphila and Faecalibacterium prausnitzii [175] was observed. The Mediterranean diet and consumption of food substances, such as green tea, caffeine or omega-3 polyunsaturated fatty acids, help to restore the changed intestinal bacterial composition $[176,177]$. A carbohydrate-restricted or fat-restricted low-calorie diet used by obese patients has led to a renewed change in the Firmicutes/Bacteroidetes ratio [178,179]. Moreover, a fiber-rich diet is associated with increased amounts of Prevotella, while a protein-rich diet is related to an increased abundance of Bacteroides [180]. After 1 month of a strict vegetarian diet, 6 obese patients with T2D and/or hypertension had significantly reduced $\mathrm{HbA}_{1 \mathrm{c}}$ and triglyceride levels, decreased body weight and improved levels of fasting and postprandial glucose. Such a diet is associated with a reduced Firmicutes/Bacteroidetes ratio and increased amounts of Clostridium and Bacteroides fragilis, which lead to diminished intestinal inflammation and SCFA levels [181].

Prebiotics are fermentable, non-digestible food components that promote the growth of bacteria in the intestine [182]. The most popular prebiotics are inulin, lactulose, galactooligosaccharides and fructooligosaccharides, and they can alter the composition of the gut microbiota [182]. Two weeks of treatment with inulin-type fructans in healthy volunteers led to increased satiety, decreased postprandial glycemia and increased postprandial release of incretins [183]. According to a meta-analysis of 20 randomized controlled trials, the supplementation of inulin-type fructans correlates positively with decreased fasting insulin levels [184]. The arabinoxylans, a new class of prebiotics, are non-digestible carbohydrates appearing in wheat and that also have potential beneficial effects on glucose metabolism [185].

Probiotics are live microorganisms, either in the form of food or supplement, which can alter the gut microbiota [182]. Lactobacillus species are the major probiotics with a glucose-lowering potential [182]. In people without altered glucose tolerance, a daily intake of Lactobacillus reuteri enhances the secretion of insulin and incretin, but the effect can be bound with an improvement of $\beta$-cell function [186]. Moreover, in another study, it was indicated that in children carrying the high-risk HLA DR3/4, a genotype bound with T1D 
susceptibility, the risk of islet autoimmunity can be decreased by the early oral exposure to probiotics [187]. In patients with metabolic syndrome, levels of uric acid were significantly decreased and the total antioxidant capacity was significantly increased after consuming probiotic yoghurt containing Lactobacillus acidophilus La5 and Bifidobacterium lactis Bb12 for 8 weeks at a dose of $300 \mathrm{~g} /$ day [188].

Synbiotics are a combination of prebiotics and probiotics. Synbiotic supplementation has the potential to decrease the serum concentration of IL- 6 , TNF- $\alpha$ and hs-CRP, which are risk factors for inflammation-dependent cardiometabolic diseases, such as T2D [189]. In patients with T2D, a diet supplemented with either prebiotics or synbiotics has the potential to preserve glucose homeostasis and improve lipid metabolism [190]. Furthermore, the administration of symbiotics can cause a decrease in body weight and diminish antiinflammatory activity [191].

Gluten intake affects the development of T1D via altering the gut microbial composition and the immune response [192]. This effect is modified by the amount, timing and mode of gluten intake [193-195]. A gluten-free diet can help to protect $\beta$-cell function by influencing the gut microbiota, which can be associated with the incidence of diabetes [192]. Furthermore, a high-fat diet can also change the composition of the intestinal microbiota, mainly by decreasing the amount of Bifidobacterium and. Administration of specific prebiotics can prevent the development of high-fat diet-induced diabetes and result in improved glucose tolerance, restored insulin secretion, decreased intestinal endotoxin levels and alleviated inflammatory response [196]. A deficiency of vitamin A increases the Firmicutes / Bacteroidetes ratio and decreases the level of bacteria producing butyrate [197]. Moreover, retinoic acid, a vitamin A metabolite, can inhibit the differentiation of pro-inflammatory Th17 cells and promote the differentiation of anti-inflammatory Treg cells [198]. These mechanisms protect against the development of T1D. Furthermore, zinc deficiency influences the inflammatory response and metabolic control, which can promote T1D incidence [199].

Another therapeutic strategy is fecal transplant. Six weeks after the infusion of the gut microbiota from lean donors to male recipients with metabolic syndrome, the levels of butyrate-producing intestinal microbiota and the insulin sensitivity of the recipients were significantly increased [168]. De Groot at al. showed that, in patients recently diagnosed with T1D, fecal microbiota transplantation in the 12 months after disease onset can halt the decline in endogenous insulin production, probably by the preservation of residual $\beta$-cell function [200]. Moreover, 3 weeks after the oral transfer of fecal bacteria in another study, the abundance of Lachnospiraceae and Clostridiaceae was increased and the amount of Lactobacillaceae was decreased, which indicates a possible improvement in insulin sensitivity in diabetic patients [201].

\section{Lacking Data and Future Directions}

Although much research about diabetes and the gut microbiota has already been performed, we are still at the beginning of the way to show the exact role of the intestinal microbiota in T1D or T2D. Until now, we have frequently based our theories on studies with rodents, but mouse microbiota differ significantly from those in humans. Moreover, the germ-free animals used in experiments are born and kept without any contact with bacteria, and are exposed to selected microbes during the research process. Retrospective and observational research has been performed that does not exactly allow the analysis of the causal relationship between gut microbiota and diabetes development. We still do not know whether the intestinal microbiota are solely involved in $\beta$-cell autoimmunity or can also activate T1D. Verification of this hypothesis will require the performance of longitudinal, interventional and prospective studies with adequate methodology and the use of human stool sample processing. Additionally, standardized and reproducible methods of analyzing genetic material are needed. Furthermore, we do not possess enough evidence to definitively prove that dysbiosis can cause T2D, or whether it just appears during the course of diabetes as a consequence of metabolic changes connected with the 
disease. Further efforts should be directed to creating such studies, which will allow the demonstration of a causal relationship between the changes in intestinal microbiota and diabetes.

\section{Conclusions}

It is of great importance to understand the exact mechanisms underlying the diseases of civilization, as their prevalence is still rising. Diabetes is one of the most common metabolic disorders and leads to serious complications and consequences. The gut microbiota is an inseparable part of human beings, and understanding its exact role in the functioning of living organisms is necessary. It is of great importance to prove whether there exists the causal relationship between diabetes development and the gut bacteria. Further research is needed, particularly unified studies that can clearly indicate exactly how the microbiota change and how they influence the host, to make the most of the potential included in the gut microbiota.

Author Contributions: Conceptualization, A.P. (Andrzej Pawlik); writing—original draft preparation, W.B. and A.P. (Agnieszka Przezak); writing-review and editing, W.B. and A.P. (Agnieszka Przezak); visualization, W.B. and A.P. (Agnieszka Przezak); supervision, A.P. (Andrzej Pawlik); funding acquisition, A.P. (Andrzej Pawlik). All authors have read and agreed to the published version of the manuscript.

Funding: The project was financed by the Minister of Science and Higher Education in the "Regional Initiative of Excellence" program, in the years 2019-2022, No. 002/RID/2018/19.

Institutional Review Board Statement: Not applicable.

Informed Consent Statement: Not applicable.

Data Availability Statement: Not applicable.

Conflicts of Interest: The authors declare no conflict of interest.

\section{References}

1. Bluestone, J.A.; Herold, K.; Eisenbarth, G. Genetics, pathogenesis and clinical interventions in type 1 diabetes. Nat. Cell Biol. 2010, 464, 1293-1300. [CrossRef] [PubMed]

2. Kahn, S.E.; Cooper, M.E.; Del Prato, S. Pathophysiology and treatment of type 2 diabetes: Perspectives on the past, present, and future. Lancet 2014, 383, 1068-1083. [CrossRef]

3. Nathan, D.M.; Cleary, P.A.; Backlund, J.-Y.C.; Genuth, S.M.; Lachin, J.; Orchard, T.; Raskin, P.; Zinman, B.; Diabetes Control and Complications Trial/Epidemiology of Diabetes Interventions and Complications (DCCT/EDIC) Study Research Group. Intensive Diabetes Treatment and Cardiovascular Disease in Patients with Type 1 Diabetes. N. Engl. J. Med. 2005, 353, 2643-2653. [CrossRef]

4. Stratton, I.M.; Adler, A.I.; Neil, H.A.W.; Matthews, D.R.; Manley, S.E.; Cull, C.A.; Hadden, D.; Turner, R.C.; Holman, R.R. Association of glycaemia with macrovascular and microvascular complications of type 2 diabetes (UKPDS 35): Prospective observational study. BMJ 2000, 321, 405-412. [CrossRef]

5. Orchard, T.; Nathan, D.M.; Zinman, B.; Cleary, P.A.; Brillon, D.; Backlund, J.-Y.C.; Lachin, J. Association Between 7 Years of Intensive Treatment of Type 1 Diabetes and Long-term Mortality. JAMA J. Am. Med Assoc. 2015, 313, 45-53. [CrossRef]

6. Saeedi, P.; Petersohn, I.; Salpea, P.; Malanda, B.; Karuranga, S.; Unwin, N.; Colagiuri, S.; Guariguata, L.; Motala, A.A.; Ogurtsova, K.; et al. Global and regional diabetes prevalence estimates for 2019 and projections for 2030 and 2045: Results from the International Diabetes Federation Diabetes Atlas, 9th edition. Diabetes Res. Clin. Pract. 2019, 157, 107843. [CrossRef]

7. Vrancken, G.; Gregory, A.C.; Huys, G.R.B.; Faust, K.; Raes, J. Synthetic ecology of the human gut microbiota. Nat. Rev. Genet. 2019, 17, 754-763. [CrossRef]

8. Faith, J.J.; Guruge, J.L.; Charbonneau, M.; Subramanian, S.; Seedorf, H.; Goodman, A.L.; Clemente, J.C.; Knight, R.; Heath, A.C.; Leibel, R.L.; et al. The Long-Term Stability of the Human Gut Microbiota. Science 2013, 341, 1237439. [CrossRef]

9. Musso, G.; Gambino, R.; Cassader, M. Interactions between Gut Microbiota and Host Metabolism Predisposing to Obesity and Diabetes. Annu. Rev. Med. 2011, 62, 361-380. [CrossRef]

10. Tang, W.W.; Kitai, T.; Hazen, S.L. Gut Microbiota in Cardiovascular Health and Disease. Circ. Res. 2017, 120, 1183-1196. [CrossRef] [PubMed]

11. Savage, D.C. Microbial ecology of the gastrointestinal tract. Annu. Rev. Microbiol. 1977, 31, 107-133. [CrossRef] [PubMed]

12. Sender, R.; Fuchs, S.; Milo, R. Revised Estimates for the Number of Human and Bacteria Cells in the Body. PLoS Biol. 2016, 14, e1002533. [CrossRef] [PubMed] 
13. The Human Microbiome Project Consortium. Structure, function and diversity of the healthy human microbiome. Nature 2012, 486, 207-214. [CrossRef] [PubMed]

14. Qin, J.; Li, R.; Raes, J.; Arumugam, M.; Burgdorf, K.S.; Manichanh, C.; Nielsen, T.; Pons, N.; Levenez, F.; Yamada, T.; et al. A human gut microbial gene catalogue established by metagenomic sequencing. Nature 2010, 464, 59-65. [CrossRef]

15. Charbonneau, M.R.; Blanton, L.V.; DiGiulio, D.B.; Relman, D.A.; Lebrilla, C.B.; Mills, D.A.; Gordon, J.I. A microbial perspective of human developmental biology. Nature 2016, 535, 48-55. [CrossRef]

16. Vallianou, N.G.; Stratigou, T.; Tsagarakis, S. Microbiome and diabetes: Where are we now? Diabetes Res. Clin. Pract. 2018, 146, 111-118. [CrossRef]

17. Rastelli, M.; Knauf, C.; Cani, P.D. Gut Microbes and Health: A Focus on the Mechanisms Linking Microbes, Obesity, and Related Disorders. Obesity 2018, 26, 792-800. [CrossRef] [PubMed]

18. Cummings, J.H.; Pomare, E.W.; Branch, W.J.; Naylor, C.P.; Macfarlane, G.T. Short chain fatty acids in human large intestine, portal, hepatic and venous blood. Gut 1987, 28, 1221-1227. [CrossRef] [PubMed]

19. Brown, A.J.; Goldsworthy, S.M.; Barnes, A.A.; Eilert, M.M.; Tcheang, L.; Daniels, D.; Muir, A.I.; Wigglesworth, M.J.; Kinghorn, I.; Fraser, N.J.; et al. The Orphan G Protein-coupled Receptors GPR41 and GPR43 Are Activated by Propionate and Other Short Chain Carboxylic Acids. J. Biol. Chem. 2003, 278, 11312-11319. [CrossRef] [PubMed]

20. Le Poul, E.; Loison, C.; Struyf, S.; Springael, J.-Y.; Lannoy, V.; Decobecq, M.-E.; Brezillon, S.; Dupriez, V.; Vassart, G.; Van Damme, J.; et al. Functional Characterization of Human Receptors for Short Chain Fatty Acids and Their Role in Polymorphonuclear Cell Activation. J. Biol. Chem. 2003, 278, 25481-25489. [CrossRef]

21. Nilsson, N.E.; Kotarsky, K.; Owman, C.; Olde, B. Identification of a free fatty acid receptor, FFA2R, expressed on leukocytes and activated by short-chain fatty acids. Biochem. Biophys. Res. Commun. 2003, 303, 1047-1052. [CrossRef]

22. Fang, Q.; Liu, N.; Zheng, B.; Guo, F.; Zeng, X.; Huang, X.; Ouyang, D. Roles of Gut Microbial Metabolites in Diabetic Kidney Disease. Front. Endocrinol. 2021, 12, 636175. [CrossRef] [PubMed]

23. Levy, M.; Thaiss, C.A.; Elinav, E. Metabolites: Messengers between the microbiota and the immune system. Genes Dev. 2016, 30, 1589-1597. [CrossRef]

24. Fukuda, S.; Toh, H.; Taylor, T.; Ohno, H.; Hattori, M. Acetate-producing bifidobacteria protect the host from enteropathogenic infection via carbohydrate transporters. Gut Microbes 2012, 3, 449-454. [CrossRef] [PubMed]

25. Scott, K.P.; Martin, J.C.; Duncan, S.; Flint, H.J. Prebiotic stimulation of human colonic butyrate-producing bacteria and bifidobacteria, in vitro. FEMS Microbiol. Ecol. 2013, 87, 30-40. [CrossRef] [PubMed]

26. Lin, H.V.; Frassetto, A.; Kowalik, E.J., Jr.; Nawrocki, A.R.; Lu, M.M.; Kosinski, J.R.; Hubert, J.A.; Szeto, D.; Yao, X.; Forrest, G.; et al. Butyrate and Propionate Protect against Diet-Induced Obesity and Regulate Gut Hormones via Free Fatty Acid Receptor 3-Independent Mechanisms. PLoS ONE 2012, 7, e35240. [CrossRef] [PubMed]

27. Burger-van Paassen, N.; Vincent, A.; Puiman, P.J.; van der Sluis, M.; Bouma, J.; Boehm, G.; van Goudoever, J.B.; van Seuningen, I.; Renes, I.B. The regulation of intestinal mucin MUC2 expression by short-chain fatty acids: Implications for epithelial protection. Biochem. J. 2009, 420, 211-219. [CrossRef] [PubMed]

28. Peng, L.; Li, Z.-R.; Green, R.S.; Holzman, I.R.; Lin, J. Butyrate Enhances the Intestinal Barrier by Facilitating Tight Junction Assembly via Activation of AMP-Activated Protein Kinase in Caco-2 Cell Monolayers. J. Nutr. 2009, 139, 1619-1625. [CrossRef] [PubMed]

29. Canfora, E.E.; Meex, R.C.R.; Venema, K.; Blaak, E.E. Gut microbial metabolites in obesity, NAFLD and T2DM. Nat. Rev. Endocrinol. 2019, 15, 261-273. [CrossRef] [PubMed]

30. Singh, N.; Gurav, A.; Sivaprakasam, S.; Brady, E.; Padia, R.; Shi, H.; Thangaraju, M.; Prasad, P.D.; Manicassamy, S.; Munn, D.H.; et al. Activation of Gpr109a, Receptor for Niacin and the Commensal Metabolite Butyrate, Suppresses Colonic Inflammation and Carcinogenesis. Immunity 2014, 40, 128-139. [CrossRef]

31. Park, J.; Kim, M.; Kang, S.G.; Jannasch, A.H.; Cooper, B.; Patterson, J.; Kim, C.H. Short-chain fatty acids induce both effector and regulatory T cells by suppression of histone deacetylases and regulation of the mTOR-S6K pathway. Mucosal Immunol. 2015, 8, 80-93. [CrossRef]

32. Kim, M.; Qie, Y.; Park, J.; Kim, C.H. Gut Microbial Metabolites Fuel Host Antibody Responses. Cell Host Microbe 2016, 20, 202-214. [CrossRef] [PubMed]

33. Purchiaroni, F.; Tortora, A.; Gabrielli, M.; Bertucci, F.; Gigante, G.; Ianiro, G.; Ojetti, V.; Scarpellini, E.; Gasbarrini, A. The role of intestinal microbiota and the immune system. Eur. Rev. Med. Pharmacol. Sci. 2013, 17, 323-333. [PubMed]

34. Ashida, H.; Ogawa, M.; Kim, M.; Mimuro, H.; Sasakawa, C. Bacteria and host interactions in the gut epithelial barrier. Nat. Chem. Biol. 2011, 8, 36-45. [CrossRef] [PubMed]

35. Clausen, M.R.; Mortensen, P.B. Kinetic studies on colonocyte metabolism of short chain fatty acids and glucose in ulcerative colitis. Gut 1995, 37, 684-689. [CrossRef]

36. Binda, C.; Lopetuso, L.R.; Rizzatti, G.; Gibiino, G.; Cennamo, V.; Gasbarrini, A. Actinobacteria: A relevant minority for the maintenance of gut homeostasis. Dig. Liver Dis. 2018, 50, 421-428. [CrossRef]

37. White, P.J.; Newgard, C.B. Branched-chain amino acids in disease. Science 2019, 363, 582-583. [CrossRef] [PubMed]

38. Pedersen, H.K.; Gudmundsdottir, V.; Nielsen, H.B.; Hyotylainen, T.; Nielsen, T.; Jensen, B.A.H.; Forslund, K.; Hildebrand, F.; Prifti, E.; Falony, G.; et al. Human gut microbes impact host serum metabolome and insulin sensitivity. Nature 2016, 535, 376-381. [CrossRef] 
39. Wang, T.J.; Larson, M.; Vasan, R.S.; Cheng, S.; Rhee, E.P.; McCabe, E.; Lewis, G.D.; Fox, C.S.; Jacques, P.F.; Fernandez, C.; et al. Metabolite profiles and the risk of developing diabetes. Nat. Med. 2011, 17, 448-453. [CrossRef] [PubMed]

40. Asghari, G.; Farhadnejad, H.; Teymoori, F.; Mirmiran, P.; Tohidi, M.; Azizi, F. High dietary intake of branched-chain amino acids is associated with an increased risk of insulin resistance in adults. J. Diabetes 2018, 10, 357-364. [CrossRef] [PubMed]

41. Karusheva, Y.; Koessler, T.; Strassburger, K.; Markgraf, D.; Mastrototaro, L.; Jelenik, T.; Simon, M.-C.; Pesta, D.; Zaharia, O.-P.; Bódis, K.; et al. Short-term dietary reduction of branched-chain amino acids reduces meal-induced insulin secretion and modifies microbiome composition in type 2 diabetes: A randomized controlled crossover trial. Am. J. Clin. Nutr. 2019, 110, 1098-1107. [CrossRef] [PubMed]

42. Vallim, T.Q.D.A.; Tarling, E.J.; Edwards, P.A. Pleiotropic Roles of Bile Acids in Metabolism. Cell Metab. 2013, 17, 657-669. [CrossRef]

43. Joyce, S.A.; Gahan, C. Disease-Associated Changes in Bile Acid Profiles and Links to Altered Gut Microbiota. Dig. Dis. 2017, 35, 169-177. [CrossRef]

44. Schmitt, J.; Kong, B.; Stieger, B.; Tschopp, O.; Schultze, S.M.; Rau, M.; Weber, A.; Mullhaupt, B.; Guo, G.L.; Geier, A. Protective effects of farnesoid X receptor (FXR) on hepatic lipid accumulation are mediated by hepatic FXR and independent of intestinal FGF15 signal. Liver Int. 2015, 35, 1133-1144. [CrossRef] [PubMed]

45. Jiang, C.; Xie, C.; Li, F.; Zhang, L.; Nichols, R.G.; Krausz, K.W.; Cai, J.; Qi, Y.; Fang, Z.-Z.; Takahashi, S.; et al. Intestinal farnesoid X receptor signaling promotes nonalcoholic fatty liver disease. J. Clin. Investig. 2015, 125, 386-402. [CrossRef] [PubMed]

46. Li, F.; Jiang, C.; Krausz, K.W.; Li, Y.; Albert, I.; Hao, H.; Fabre, K.M.; Mitchell, J.B.; Patterson, A.; Gonzalez, F.J. Microbiome remodelling leads to inhibition of intestinal farnesoid $X$ receptor signalling and decreased obesity. Nat. Commun. 2013, 4, 2384. [CrossRef] [PubMed]

47. Thomas, C.; Gioiello, A.; Noriega, L.; Strehle, A.; Oury, J.; Rizzo, G.; Macchiarulo, A.; Yamamoto, H.; Mataki, C.; Pruzanski, M.; et al. TGR5-Mediated Bile Acid Sensing Controls Glucose Homeostasis. Cell Metab. 2009, 10, 167-177. [CrossRef] [PubMed]

48. Trabelsi, M.-S.; Daoudi, M.; Prawitt, J.; Ducastel, S.; Touche, V.; Sayin, S.I.; Perino, A.; Brighton, C.A.; Sebti, Y.; Kluza, J.; et al. Farnesoid $X$ receptor inhibits glucagon-like peptide-1 production by enteroendocrine L cells. Nat. Commun. 2015, 6, 7629. [CrossRef] [PubMed]

49. Sayin, S.I.; Wahlström, A.; Felin, J.; Jäntti, S.; Marschall, H.-U.; Bamberg, K.; Angelin, B.; Hyötyläinen, T.; Oresic, M.; Bäckhed, F. Gut Microbiota Regulates Bile Acid Metabolism by Reducing the Levels of Tauro-beta-muricholic Acid, a Naturally Occurring FXR Antagonist. Cell Metab. 2013, 17, 225-235. [CrossRef] [PubMed]

50. Bäckhed, F.; Fraser, C.M.; Ringel, Y.; Sanders, M.E.; Sartor, R.B.; Sherman, P.M.; Versalovic, J.; Young, V.; Finlay, B.B. Defining a Healthy Human Gut Microbiome: Current Concepts, Future Directions, and Clinical Applications. Cell Host Microbe 2012, 12, 611-622. [CrossRef] [PubMed]

51. Chun, E.; Lavoie, S.; Fonseca-Pereira, D.; Bae, S.; Michaud, M.; Hoveyda, H.R.; Fraser, G.L.; Gallini Comeau, C.A.; Glickman, J.N.; Fuller, M.H.; et al. Metabolite-Sensing Receptor Ffar2 Regulates Colonic Group 3 Innate Lymphoid Cells and Gut Immunity. Immunity 2019, 51, 871-884.e6. [CrossRef]

52. Schirmer, M.; Smeekens, S.P.; Vlamakis, H.; Jaeger, M.; Oosting, M.; Franzosa, E.A.; Ter Horst, R.; Jansen, T.; Jacobs, L.; Bonder, M.J.; et al. Linking the Human Gut Microbiome to Inflammatory Cytokine Production Capacity. Cell 2016, 167, 1125-1136. [CrossRef]

53. Bachem, A.; Makhlouf, C.; Binger, K.J.; de Souza, D.P.; Tull, D.; Hochheiser, K.; Whitney, P.G.; Fernandez-Ruiz, D.; Dähling, S.; Kastenmüller, W.; et al. Microbiota-Derived Short-Chain Fatty Acids Promote the Memory Potential of Antigen-Activated CD8+ T Cells. Immunity 2019, 51, 285-297.e5. [CrossRef]

54. Schulthess, J.; Pandey, S.; Capitani, M.; Rue-Albrecht, K.C.; Arnold, I.; Franchini, F.; Chomka, A.; Ilott, N.E.; Johnston, D.G.W.; Pires, E.; et al. The Short Chain Fatty Acid Butyrate Imprints an Antimicrobial Program in Macrophages. Immunity 2019, 50, 432-445. [CrossRef]

55. Hill, M.J. Intestinal flora and endogenous vitamin synthesis. Eur. J. Cancer Prev. 1997, 6, S43-S45. [CrossRef]

56. Bäckhed, F.; Ley, R.E.; Sonnenburg, J.L.; Peterson, D.A.; Gordon, J.I. Host-Bacterial Mutualism in the Human Intestine. Science 2005, 307, 1915-1920. [CrossRef]

57. Mirpuri, J.; Raetz, M.; Sturge, C.R.; Wilhelm, C.L.; Benson, A.; Savani, R.C.; Hooper, L.V.; Yarovinsky, F. Proteobacteria-specific IgA regulates maturation of the intestinal microbiota. Gut Microbes 2013, 5, 28-39. [CrossRef]

58. Shin, N.-R.; Whon, T.W.; Bae, J.-W. Proteobacteria: Microbial signature of dysbiosis in gut microbiota. Trends Biotechnol. 2015, 33, 496-503. [CrossRef]

59. Vaughn, A.C.; Cooper, E.M.; DiLorenzo, P.M.; O’Loughlin, L.J.; Konkel, M.E.; Peters, J.H.; Hajnal, A.; Sen, T.; Lee, S.H.; de La Serre, C.B.; et al. Energy-dense diet triggers changes in gut microbiota, reorganization of gut-brain vagal communication and increases body fat accumulation. Acta Neurobiol. Exp. 2017, 77, 18-30. [CrossRef] [PubMed]

60. Han, H.; Li, Y.; Fang, J.; Liu, G.; Yin, J.; Li, T.; Yin, Y. Gut Microbiota and Type 1 Diabetes. Int. J. Mol. Sci. 2018, 19, 995. [CrossRef]

61. Giongo, A.; Gano, K.A.; Crabb, D.B.; Mukherjee, N.; Novelo, L.L.; Casella, G.; Drew, J.C.; Ilonen, J.; Knip, M.; Hyoty, H.; et al. Toward defining the autoimmune microbiome for type 1 diabetes. ISME J. 2011, 5, 82-91. [CrossRef] [PubMed]

62. de Goffau, M.; Fuentes, S.; Bogert, B.V.D.; Honkanen, H.; De Vos, W.M.; Welling, G.W.; Hyoty, H.; Harmsen, H.J.M. Aberrant gut microbiota composition at the onset of type 1 diabetes in young children. Diabetologia 2014, 57, 1569-1577. [CrossRef] 
63. Mejía-León, M.E.; Petrosino, J.F.; Ajami, N.J.; Domínguez-Bello, M.G.; De La Barca, A.M.C. Fecal microbiota imbalance in Mexican children with type 1 diabetes. Sci. Rep. 2015, 4, 3814. [CrossRef] [PubMed]

64. Vatanen, T.; Franzosa, E.A.; Schwager, R.; Tripathi, S.; Arthur, T.D.; Vehik, K.; Lernmark, Å.; Hagopian, W.A.; Rewers, M.J.; She, J.-X.; et al. The human gut microbiome in early-onset type 1 diabetes from the TEDDY study. Nature 2018, 562, 589-594. [CrossRef]

65. Pellegrini, S.; Sordi, V.; Bolla, A.M.; Saita, D.; Ferrarese, R.; Canducci, F.; Clementi, M.; Invernizzi, F.; Mariani, A.; Bonfanti, R.; et al. Duodenal Mucosa of Patients with Type 1 Diabetes Shows Distinctive Inflammatory Profile and Microbiota. J. Clin. Endocrinol. Metab. 2017, 102, 1468-1477. [CrossRef]

66. Siljander, H.; Honkanen, J.; Knip, M. Microbiome and type 1 diabetes. EBioMedicine 2019, 46, 512-521. [CrossRef]

67. Kemppainen, K.M.; Ardissone, A.N.; Davis-Richardson, A.G.; Fagen, J.R.; Gano, K.A.; León-Novelo, L.G.; Vehik, K.; Casella, G.; Simell, O.; Ziegler, A.G.; et al. Early Childhood Gut Microbiomes Show Strong Geographic Differences among Subjects at High Risk for Type 1 Diabetes. Diabetes Care 2014, 38, 329-332. [CrossRef]

68. Larsen, N.; Vogensen, F.K.; Van Den Berg, F.W.J.; Nielsen, D.S.; Andreasen, A.S.; Pedersen, B.K.; Al-Soud, W.A.; Sørensen, S.J.; Hansen, L.H.; Jakobsen, M. Gut Microbiota in Human Adults with Type 2 Diabetes Differs from Non-Diabetic Adults. PLoS ONE 2010, 5, e9085. [CrossRef]

69. Qin, J.; Li, Y.; Cai, Z.; Li, S.; Zhu, J.; Zhang, F.; Liang, S.; Zhang, W.; Guan, Y.; Shen, D.; et al. A metagenome-wide association study of gut microbiota in type 2 diabetes. Nature 2012, 490, 55-60. [CrossRef]

70. Karlsson, F.H.; Tremaroli, V.; Nookaew, I.; Bergström, G.; Behre, C.J.; Fagerberg, B.; Nielsen, J.; Bäckhed, F. Gut metagenome in European women with normal, impaired and diabetic glucose control. Nature 2013, 498, 99-103. [CrossRef]

71. Zhang, Y.; Zhang, H. Microbiota associated with type 2 diabetes and its related complications. Food Sci. Hum. Wellness 2013, 2 , 167-172. [CrossRef]

72. Allin, K.H.; Tremaroli, V.; Caesar, R.; Jensen, B.A.H.; Damgaard, M.T.F.; Bahl, M.I.; Licht, T.R.; Hansen, T.H.; Nielsen, T.; Dantoft, T.M.; et al. Aberrant intestinal microbiota in individuals with prediabetes. Diabetologia 2018, 61, 810-820. [CrossRef]

73. Sedighi, M.; Razavi, S.; Navab-Moghadam, F.; Khamseh, M.E.; Alaei-Shahmiri, F.; Mehrtash, A.; Amirmozafari, N. Comparison of gut microbiota in adult patients with type 2 diabetes and healthy individuals. Microb. Pathog. 2017, 111, 362-369. [CrossRef]

74. Zhao, L.; Lou, H.; Peng, Y.; Chen, S.; Zhang, Y.; Li, X. Comprehensive relationships between gut microbiome and faecal metabolome in individuals with type 2 diabetes and its complications. Endocrine 2019, 66, 526-537. [CrossRef]

75. Devaraj, S.; Dasu, M.R.; Jialal, I. Diabetes is a proinflammatory state: A translational perspective. Expert Rev. Endocrinol. Metab. 2010, 5, 19-28. [CrossRef]

76. Hu, Y.; Wong, F.S.; Wen, L. Antibiotics, gut microbiota, environment in early life and type 1 diabetes. Pharmacol. Res. 2017, 119, 219-226. [CrossRef] [PubMed]

77. Achenbach, P.; Bonifacio, E.; Koczwara, K.; Ziegler, A.-G. Natural History of Type 1 Diabetes. Diabetes 2005, 54, S25-S31. [CrossRef] [PubMed]

78. Rewers, M.; Ludvigsson, J. Environmental risk factors for type 1 diabetes. Lancet 2016, 387, 2340-2348. [CrossRef]

79. Milani, C.; Duranti, S.; Bottacini, F.; Casey, E.; Turroni, F.; Mahony, J.; Belzer, C.; Palacio, S.D.; Montes, S.A.; Mancabelli, L.; et al The First Microbial Colonizers of the Human Gut: Composition, Activities, and Health Implications of the Infant Gut Microbiota. Microbiol. Mol. Biol. Rev. 2017, 81, e00036-17. [CrossRef]

80. Ding, T.; Schloss, P.D. Dynamics and associations of microbial community types across the human body. Nature 2014, 509, 357-360. [CrossRef] [PubMed]

81. Zhou, H.; Sun, L.; Zhang, S.; Zhao, X.; Gang, X.; Wang, G. The crucial role of early-life gut microbiota in the development of type 1 diabetes. Acta Diabetol. 2021, 58, 249-265. [CrossRef]

82. Bonder, M.J.; Kurilshikov, A.; Tigchelaar, E.F.; Mujagic, Z.; Imhann, F.; Vila, A.V.; Deelen, P.; Vatanen, T.; Schirmer, M.; Smeekens, S.P.; et al. The effect of host genetics on the gut microbiome. Nat. Genet. 2016, 48, 1407-1412. [CrossRef]

83. Alkanani, A.K.; Hara, N.; Gottlieb, P.A.; Ir, D.; Robertson, C.E.; Wagner, B.D.; Frank, D.N.; Zipris, D. Alterations in Intestinal Microbiota Correlate With Susceptibility to Type 1 Diabetes. Diabetes 2015, 64, 3510-3520. [CrossRef] [PubMed]

84. Pinto, E.; Anselmo, M.; Calha, M.; Bottrill, A.; Duarte, G.I.D.S.; Andrew, P.W.; Faleiro, M.L. The intestinal proteome of diabetic and control children is enriched with different microbial and host proteins. Microbiology 2017, 163, 161-174. [CrossRef]

85. Gavin, P.G.; Mullaney, J.A.; Loo, D.; Cao, K.-A.L.; Gottlieb, P.A.; Hill, M.M.; Zipris, D.; Hamilton-Williams, E.E. Intestinal Metaproteomics Reveals Host-Microbiota Interactions in Subjects at Risk for Type 1 Diabetes. Diabetes Care 2018, 41, 2178-2186. [CrossRef]

86. Hooper, L.V.; Midtvedt, T.; Gordon, J.I. How host-microbial interactions shape the nutrient environment of the mammalian intestine. Annu. Rev. Nutr. 2002, 22, 283-307. [CrossRef]

87. Ma, Q.; Li, Y.; Wang, J.; Li, P.; Duan, Y.; Dai, H.; An, Y.; Cheng, L.; Wang, T.; Wang, C.; et al. Investigation of gut microbiome changes in type 1 diabetic mellitus rats based on high-throughput sequencing. Biomed. Pharmacother. 2020, 124, 109873. [CrossRef]

88. Bosi, E.; Molteni, L.; Radaelli, M.G.; Folini, L.; Fermo, I.; Bazzigaluppi, E.; Piemonti, L.; Pastore, M.R.; Paroni, R. Increased intestinal permeability precedes clinical onset of type 1 diabetes. Diabetologia 2006, 49, 2824-2827. [CrossRef]

89. Finnie, I.A.; Dwarakanath, A.D.; Taylor, B.A.; Rhodes, J.M. Colonic mucin synthesis is increased by sodium butyrate. Gut 1995, 36, 93-99. [CrossRef] 
90. Peng, L.; He, Z.; Chen, W.; Holzman, I.R.; Lin, J. Effects of Butyrate on Intestinal Barrier Function in a Caco-2 Cell Monolayer Model of Intestinal Barrier. Pediatr. Res. 2007, 61, 37-41. [CrossRef]

91. Louis, P.; Flint, H.J. Diversity, metabolism and microbial ecology of butyrate-producing bacteria from the human large intestine. FEMS Microbiol. Lett. 2009, 294, 1-8. [CrossRef] [PubMed]

92. Li, W.-Z.; Stirling, K.; Yang, J.-J.; Zhang, L. Gut microbiota and diabetes: From correlation to causality and mechanism. World J. Diabetes 2020, 11, 293-308. [CrossRef] [PubMed]

93. Mariño, E.; Richards, J.L.; McLeod, K.H.; Stanley, D.; Yap, Y.A.; Knight, J.; McKenzie, C.; Kranich, J.; Oliveira, A.C.; Rossello, F.J.; et al. Gut microbial metabolites limit the frequency of autoimmune T cells and protect against type 1 diabetes. Nat. Immunol. 2017, 18, 552-562. [CrossRef]

94. Velloso, L.A.; Folli, F.; Saad, M.J. TLR4 at the Crossroads of Nutrients, Gut Microbiota, and Metabolic Inflammation. Endocr. Rev. 2015, 36, 245-271. [CrossRef]

95. Li, J.; Wang, X.; Zhang, F.; Yin, H. Toll-like receptors as therapeutic targets for autoimmune connective tissue diseases. Pharmacol. Ther. 2013, 138, 441-451. [CrossRef]

96. Devaraj, S.; Dasu, M.R.; Park, S.H.; Jialal, I. Increased levels of ligands of Toll-like receptors 2 and 4 in type 1 diabetes. Diabetologia 2009, 52, 1665-1668. [CrossRef]

97. Allin, K.H.; Nielsen, T.; Pedersen, O. Mechanisms in endocrinology: Gut microbiota in patients with type 2 diabetes mellitus. Eur. J. Endocrinol. 2015, 172, R167-R177. [CrossRef] [PubMed]

98. Vatanen, T.; Kostic, A.; D’Hennezel, E.; Siljander, H.; Franzosa, E.A.; Yassour, M.; Kolde, R.; Vlamakis, H.; Arthur, T.D.; Hämäläinen, A.-M.; et al. Variation in Microbiome LPS Immunogenicity Contributes to Autoimmunity in Humans. Cell 2016, 165, 842-853. [CrossRef]

99. Kihl, P.; Krych, L.; Deng, L.; Kildemoes, A.O.; Laigaard, A.; Hansen, L.H.; Hansen, C.H.F.; Buschard, K.; Nielsen, D.S.; Hansen, A.K. Oral LPS Dosing Induces Local Immunological Changes in the Pancreatic Lymph Nodes in Mice. J. Diabetes Res. 2019, 2019, 1649279. [CrossRef]

100. Festi, D.; Schiumerini, R.; Eusebi, L.H.; Marasco, G.; Taddia, M.; Colecchia, A. Gut microbiota and metabolic syndrome. World J. Gastroenterol. 2014, 20, 16079-16094. [CrossRef]

101. Gurung, M.; Li, Z.; You, H.; Rodrigues, R.; Jump, D.B.; Morgun, A.; Shulzhenko, N. Role of gut microbiota in type 2 diabetes pathophysiology. EBioMedicine 2020, 51, 102590. [CrossRef] [PubMed]

102. Bond, P.; Hugenholtz, P.; Keller, J.; Blackall, L.L. Bacterial community structures of phosphate-removing and non-phosphateremoving activated sludges from sequencing batch reactors. Appl. Environ. Microbiol. 1995, 61, 1910-1916. [CrossRef]

103. Knight, R.; Callewaert, C.; Marotz, C.; Hyde, E.R.; Debelius, J.; McDonald, D.; Sogin, M.L. The Microbiome and Human Biology. Annu. Rev. Genom. Hum. Genet. 2017, 18, 65-86. [CrossRef] [PubMed]

104. Candela, M.; Biagi, E.; Soverini, M.; Consolandi, C.; Quercia, S.; Severgnini, M.; Peano, C.; Turroni, S.; Rampelli, S.; Pozzilli, P.; et al. Modulation of gut microbiota dysbioses in type 2 diabetic patients by macrobiotic Ma-Pi 2 diet. Br. J. Nutr. 2016, 116, 80-93. [CrossRef]

105. Lippert, K.; Kedenko, L.; Antonielli, L.; Kedenko, I.; Gemeier, C.; Leitner, M.; Kautzky-Willer, A.; Paulweber, B.; Hackl, E. Gut microbiota dysbiosis associated with glucose metabolism disorders and the metabolic syndrome in older adults. Benef. Microbes 2017, 8, 545-556. [CrossRef]

106. Yamaguchi, Y.; Adachi, K.; Sugiyama, T.; Shimozato, A.; Ebi, M.; Ogasawara, N.; Funaki, Y.; Goto, C.; Sasaki, M.; Kasugai, K. Association of Intestinal Microbiota with Metabolic Markers and Dietary Habits in Patients with Type 2 Diabetes. Digestion 2016, 94, 66-72. [CrossRef]

107. Wu, X.; Ma, C.; Han, L.; Nawaz, M.; Gao, F.; Zhang, X.; Yu, P.; Zhao, C.; Li, L.; Zhou, A.; et al. Molecular Characterisation of the Faecal Microbiota in Patients with Type II Diabetes. Curr. Microbiol. 2010, 61, 69-78. [CrossRef] [PubMed]

108. Zhang, X.; Shen, D.; Fang, Z.; Jie, Z.; Qiu, X.; Zhang, C.; Chen, Y.; Ji, L. Human Gut Microbiota Changes Reveal the Progression of Glucose Intolerance. PLOS ONE 2013, 8, e71108. [CrossRef] [PubMed]

109. Murphy, R.; Tsai, P.; Jüllig, M.; Liu, A.; Plank, L.; Booth, M. Differential Changes in Gut Microbiota after Gastric Bypass and Sleeve Gastrectomy Bariatric Surgery Vary According to Diabetes Remission. Obes. Surg. 2016, 27, 917-925. [CrossRef]

110. Yang, J.-Y.; Lee, Y.-S.; Kim, Y.; Lee, S.-H.; Ryu, S.; Fukuda, S.; Hase, K.; Yang, C.-S.; Lim, H.S.; Kim, M.-S.; et al. Gut commensal Bacteroides acidifaciens prevents obesity and improves insulin sensitivity in mice. Mucosal Immunol. 2017, 10, 104-116. [CrossRef] [PubMed]

111. Gauffin-Cano, P.; Santacruz, A.; Moya, Á.; Sanz, Y. Bacteroides uniformis CECT 7771 Ameliorates Metabolic and Immunological Dysfunction in Mice with High-Fat-Diet Induced Obesity. PLoS ONE 2012, 7, e41079. [CrossRef]

112. Salamon, D.; Sroka-Oleksiak, A.; Kapusta, P.; Szopa, M.; Mrozińska, S.; Ludwig-Słomczyńska, A.H.; Wołkow, P.P.; Bulanda, M.; Klupa, T.; Małecki, M.T.; et al. Characteristics of the gut microbiota in adult patients with type 1 and 2 diabetes based on the analysis of a fragment of 16S rRNA gene using next-generation sequencing. Pol. Arch. Intern. Med. 2018, 128, 336-343. [CrossRef]

113. Gao, R.; Zhu, C.; Li, H.; Yin, M.; Pan, C.; Huang, L.; Kong, C.; Wang, X.; Zhang, Y.; Qu, S.; et al. Dysbiosis Signatures of Gut Microbiota along the Sequence from Healthy, Young Patients to Those with Overweight and Obesity. Obesity 2018, 26, 351-361. [CrossRef] [PubMed] 
114. Graessler, J.; Qin, Y.; Zhong, H.; Zhang, J.; Licinio, J.; Wong, M.L.; Xu, A.; Chavakis, T.; Bornstein, A.B.; Ehrhart-Bornstein, M.; et al. Metagenomic sequencing of the human gut microbiome before and after bariatric surgery in obese patients with type 2 diabetes: Correlation with inflammatory and metabolic parameters. Pharm. J. 2013, 13, 514-522. [CrossRef]

115. Forslund, K.; Hildebrand, F.; Nielsen, T.; Falony, G.; Le Chatelier, E.; Sunagawa, S.; Prifti, E.; Vieira-Silva, S.; Gudmundsdottir, V.; Pedersen, H.K.; et al. Disentangling type 2 diabetes and metformin treatment signatures in the human gut microbiota. Nature 2015, 528, 262-266, Correction in 2017, 545, 116. [CrossRef]

116. Le, T.K.C.; Hosaka, T.; Nguyen, T.T.; Kassu, A.; Dang, T.O.; Tran, H.B.; Pham, P.T.; Tran, Q.B.; Da Pham, X. Bifidobacterium species lower serum glucose, increase expressions of insulin signaling proteins, and improve adipokine profile in diabetic mice. Biomed. Res. 2015, 36, 63-70. [CrossRef]

117. Kikuchi, K.; Ben Othman, M.; Sakamoto, K. Sterilized bifidobacteria suppressed fat accumulation and blood glucose level. Biochem. Biophys. Res. Commun. 2018, 501, 1041-1047. [CrossRef] [PubMed]

118. Roden, M.; Shulman, G.I. The integrative biology of type 2 diabetes. Nature 2019, 576, 51-60. [CrossRef] [PubMed]

119. DeFronzo, R.A. Banting Lecture. From the Triumvirate to the Ominous Octet: A New Paradigm for the Treatment of Type 2 Diabetes Mellitus. Diabetes 2009, 58, 773-795. [CrossRef] [PubMed]

120. Gregor, M.F.; Hotamisligil, G.S. Inflammatory Mechanisms in Obesity. Annu. Rev. Immunol. 2011, 29, 415-445. [CrossRef] [PubMed]

121. Bellou, V.; Belbasis, L.; Tzoulaki, I.; Evangelou, E. Risk factors for type 2 diabetes mellitus: An exposure-wide umbrella review of meta-analyses. PLoS ONE 2018, 13, e0194127. [CrossRef] [PubMed]

122. Carey, V.J.; Walters, E.E.; Colditz, G.; Solomon, C.G.; Willet, W.C.; Rosner, B.A.; Speizer, F.E.; Manson, J.E. Body Fat Distribution and Risk of Non-Insulin-dependent Diabetes Mellitus in Women: The Nurses' Health Study. Am. J. Epidemiol. 1997, 145, 614-619. [CrossRef]

123. Sinha, R.; Dufour, S.; Petersen, K.F.; LeBon, V.; Enoksson, S.; Ma, Y.-Z.; Savoye, M.; Rothman, D.L.; Shulman, G.I.; Caprio, S. Assessment of Skeletal Muscle Triglyceride Content by $1 \mathrm{H}$ Nuclear Magnetic Resonance Spectroscopy in Lean and Obese Adolescents: Relationships to Insulin Sensitivity, Total Body Fat, and Central Adiposity. Diabetes 2002, 51, 1022-1027. [CrossRef]

124. Bäckhed, F.; Manchester, J.K.; Semenkovich, C.F.; Gordon, J.I. Mechanisms underlying the resistance to diet-induced obesity in germ-free mice. Proc. Natl. Acad. Sci. USA 2007, 104, 979-984. [CrossRef]

125. Rabot, S.; Membrez, M.; Bruneau, A.; Gérard, P.; Harach, T.; Moser, M.; Raymond, F.; Mansourian, R.; Chou, C.J. Germ-free C57BL/6J mice are resistant to high-fat-diet-induced insulin resistance and have altered cholesterol metabolism. FASEB J. 2010, 24, 4948-4959. [CrossRef]

126. Fei, N.; Zhao, L. An opportunistic pathogen isolated from the gut of an obese human causes obesity in germfree mice. ISME J. 2012, 7, 880-884. [CrossRef] [PubMed]

127. Turnbaugh, P.J.; Ley, R.E.; Mahowald, M.A.; Magrini, V.; Mardis, E.R.; Gordon, J.I. An obesity-associated gut microbiome with increased capacity for energy harvest. Nature 2006, 444, 1027-1031. [CrossRef]

128. Ridaura, V.K.; Faith, J.J.; Rey, F.E.; Cheng, J.; Duncan, A.E.; Kau, A.L.; Griffin, N.W.; Lombard, V.; Henrissat, B.; Bain, J.R.; et al. Gut Microbiota from Twins Discordant for Obesity Modulate Metabolism in Mice. Science 2013, 341, 1241214. [CrossRef]

129. Sanna, S.; Van Zuydam, N.R.; Mahajan, A.; Kurilshikov, A.; Vila, A.V.; Võsa, U.; Mujagic, Z.; Masclee, A.A.M.; Jonkers, D.M.A.E.; Oosting, M.; et al. Causal relationships among the gut microbiome, short-chain fatty acids and metabolic diseases. Nat. Genet. 2019, 51, 600-605. [CrossRef]

130. Macfarlane, G.T.; Macfarlane, S. Fermentation in the Human Large Intestine: Its physiologic consequences and the potential contribution of prebiotics. J. Clin. Gastroenterol. 2011, 45, S120-S127. [CrossRef]

131. Chang, P.V.; Hao, L.; Offermanns, S.; Medzhitov, R. The microbial metabolite butyrate regulates intestinal macrophage function via histone deacetylase inhibition. Proc. Natl. Acad. Sci. USA 2014, 111, 2247-2252. [CrossRef]

132. Furusawa, Y.; Obata, Y.; Fukuda, S.; Endo, T.A.; Nakato, G.; Takahashi, D.; Nakanishi, Y.; Uetake, C.; Kato, K.; Kato, T.; et al Commensal microbe-derived butyrate induces the differentiation of colonic regulatory T cells. Nature 2013, 504, 446-450. [CrossRef] [PubMed]

133. Wang, H.; Hou, L.; Kwak, D.; Fassett, J.; Xu, X.; Chen, A.; Chen, W.; Blazar, B.R.; Xu, Y.; Hall, J.L.; et al. Increasing Regulatory T Cells with Interleukin-2 and Interleukin-2 Antibody Complexes Attenuates Lung Inflammation and Heart Failure Progression. Hypertension 2016, 68, 114-122. [CrossRef] [PubMed]

134. De Vadder, F.; Kovatcheva-Datchary, P.; Goncalves, D.; Vinera, J.; Zitoun, C.; Duchampt, A.; Bäckhed, F.; Mithieux, G. MicrobiotaGenerated Metabolites Promote Metabolic Benefits via Gut-Brain Neural Circuits. Cell 2014, 156, 84-96. [CrossRef]

135. Cunningham, A.L.; Stephens, J.W.; Harris, D.A. Gut microbiota influence in type 2 diabetes mellitus (T2DM). Gut Pathog. 2021, 13, 50. [CrossRef]

136. van den Munckhof, I.C.L.; Kurilshikov, A.; Ter Horst, R.; Riksen, N.P.; Joosten, L.A.B.; Zhernakova, A.; Fu, J.; Keating, S.; Netea, M.G.; De Graaf, J.; et al. Role of gut microbiota in chronic low-grade inflammation as potential driver for atherosclerotic cardiovascular disease: A systematic review of human studies. Obes. Rev. 2018, 19, 1719-1734. [CrossRef] [PubMed]

137. Noureldein, M.H.; Bitar, S.; Youssef, N.; Azar, S.; Eid, A.A. Butyrate modulates diabetes-linked gut dysbiosis: Epigenetic and mechanistic modifications. J. Mol. Endocrinol. 2020, 64, 29-42. [CrossRef] [PubMed] 
138. Matheus, V.A.; Monteiro, L.; Oliveira, R.B.; Maschio, D.A.; Collares-Buzato, C.B. Butyrate reduces high-fat diet-induced metabolic alterations, hepatic steatosis and pancreatic beta cell and intestinal barrier dysfunctions in prediabetic mice. Exp. Biol. Med. 2017, 242, 1214-1226. [CrossRef] [PubMed]

139. Zeng, Y.; Mtintsilana, A.; Goedecke, J.H.; Micklesfield, L.K.; Olsson, T.; Chorell, E. Alterations in the metabolism of phospholipids, bile acids and branched-chain amino acids predicts development of type 2 diabetes in black South African women: A prospective cohort study. Metabolism 2019, 95, 57-64. [CrossRef]

140. Hansen, M.; Sonne, D.P.; Knop, F.K. Bile Acid Sequestrants: Glucose-Lowering Mechanisms and Efficacy in Type 2 Diabetes. Curr. Diabetes Rep. 2014, 14, 482. [CrossRef] [PubMed]

141. Cani, P.D.; Amar, J.; Iglesias, M.A.; Poggi, M.; Knauf, C.; Bastelica, D.; Neyrinck, A.M.; Fava, F.; Tuohy, K.M.; Chabo, C.; et al. Metabolic Endotoxemia Initiates Obesity and Insulin Resistance. Diabetes 2007, 56, 1761-1772. [CrossRef]

142. Shi, H.; Kokoeva, M.V.; Inouye, K.; Tzameli, I.; Yin, H.; Flier, J.S. TLR4 links innate immunity and fatty acid-induced insulin resistance. J. Clin. Investig. 2006, 116, 3015-3025. [CrossRef]

143. Medzhitov, R. Toll-like receptors and innate immunity. Nat. Rev. Immunol. 2001, 1, 135-145. [CrossRef]

144. Medzhitov, R.; Horng, T. Transcriptional control of the inflammatory response. Nat. Rev. Immunol. 2009, 9, 692-703. [CrossRef] [PubMed]

145. Folli, F.; Kahn, C.R.; Hansen, H.; Bouchie, J.L.; Feener, E.P. Angiotensin II inhibits insulin signaling in aortic smooth muscle cells at multiple levels. A potential role for serine phosphorylation in insulin/angiotensin II crosstalk. J. Clin. Investig. 1997, 100, 2158-2169. [CrossRef]

146. Samuel, V.T.; Shulman, G.I. Mechanisms for Insulin Resistance: Common Threads and Missing Links. Cell 2012, 148, 852-871. [CrossRef]

147. Sugita, H.; Kaneki, M.; Tokunaga, E.; Sugita, M.; Koike, C.; Yasuhara, S.; Tompkins, R.G.; Martyn, J.A.J. Inducible nitric oxide synthase plays a role in LPS-induced hyperglycemia and insulin resistance. Am. J. Physiol. Metab. 2002, 282, E386-E394. [CrossRef]

148. Symeonides, S.; Balk, R.A. Nitric oxide in the pathogenesis of sepsis. Infect. Dis. Clin. N. Am. 1999, 13, 449-463. [CrossRef]

149. Stamler, J.S.; Toone, E.J.; Lipton, S.A.; Sucher, N.J. (S)NO Signals: Translocation, Regulation, and a Consensus Motif. Neuron 1997, 18, 691-696. [CrossRef]

150. Stamler, J.S.; Simon, D.I.; Osborne, J.A.; Mullins, M.E.; Jaraki, O.; Michel, T.; Singel, D.J.; Loscalzo, J. S-nitrosylation of proteins with nitric oxide: Synthesis and characterization of biologically active compounds. Proc. Natl. Acad. Sci. USA 1992, 89, 444-448. [CrossRef]

151. Carvalho-Filho, M.A.; Ueno, M.; Hirabara, S.M.; Seabra, A.B.; Carvalheira, J.B.; de Oliveira, M.G.; Velloso, L.A.; Curi, R.; Saad, M.J. S-Nitrosation of the Insulin Receptor, Insulin Receptor Substrate 1, and Protein Kinase B/Akt: A Novel Mechanism of Insulin Resistance. Diabetes 2005, 54, 959-967. [CrossRef]

152. Gomes, J.M.G.; Costa, J.d.A.; Alfenas, R.d.C.G. Metabolic endotoxemia and diabetes mellitus: A systematic review. Metabolism 2017, 68, 133-144. [CrossRef] [PubMed]

153. Cani, P.D.; Bibiloni, R.; Knauf, C.; Waget, A.; Neyrinck, A.M.; Delzenne, N.M.; Burcelin, R. Changes in Gut Microbiota Control Metabolic Endotoxemia-Induced Inflammation in High-Fat Diet-Induced Obesity and Diabetes in Mice. Diabetes 2008, 57, 1470-1481. [CrossRef]

154. Jumpertz, R.; Le, D.S.; Turnbaugh, P.J.; Trinidad, C.; Bogardus, C.; Gordon, J.I.; Krakoff, J. Energy-balance studies reveal associations between gut microbes, caloric load, and nutrient absorption in humans. Am. J. Clin. Nutr. 2011, 94, 58-65. [CrossRef]

155. Patterson, A.M.; Mulder, I.E.; Travis, A.; Lan, A.; Cerf-Bensussan, N.; Gaboriau-Routhiau, V.; Garden, K.; Logan, E.; Delday, M.I.; Coutts, A.G.P.; et al. Human Gut Symbiont Roseburia hominis Promotes and Regulates Innate Immunity. Front. Immunol. 2017, 8, 1166. [CrossRef]

156. Van den Abbeele, P.; Belzer, C.; Goossens, M.; Kleerebezem, M.; De Vos, W.M.; Thas, O.; De Weirdt, R.; Kerckhof, F.-M.; Van De Wiele, T. Butyrate-producing Clostridium cluster XIVa species specifically colonize mucins in an in vitro gut model. ISME J. 2013, 7, 949-961. [CrossRef]

157. Juge, N. Microbial adhesins to gastrointestinal mucus. Trends Microbiol. 2012, 20, 30-39. [CrossRef] [PubMed]

158. Barcenilla, A.; Pryde, S.E.; Martin, J.C.; Duncan, S.; Stewart, C.S.; Henderson, C.; Flint, H.J. Phylogenetic Relationships of Butyrate-Producing Bacteria from the Human Gut. Appl. Environ. Microbiol. 2000, 66, 1654-1661. [CrossRef]

159. Duncan, S.H.; Hold, G.; Harmsen, H.J.M.; Stewart, C.S.; Flint, H.J. Growth requirements and fermentation products of Fusobacterium prausnitzii, and a proposal to reclassify it as Faecalibacterium prausnitzii gen. nov., comb. nov. Int. J. Syst. Evol. Microbiol. 2002, 52, 2141-2146. [CrossRef]

160. Miquel, S.; Martin, R.; Rossi, O.; Humaran, L.G.B.; Chatel, J.; Sokol, H.; Thomas, M.; Wells, J.; Langella, P. Faecalibacterium prausnitzii and human intestinal health. Curr. Opin. Microbiol. 2013, 16, 255-261. [CrossRef]

161. Sokol, H.; Pigneur, B.; Watterlot, L.; Lakhdari, O.; Bermúdez-Humaran, L.G.; Gratadoux, J.-J.; Blugeon, S.; Bridonneau, C.; Furet, J.-P.; Corthier, G.; et al. Faecalibacterium prausnitzii is an anti-inflammatory commensal bacterium identified by gut microbiota analysis of Crohn disease patients. Proc. Natl. Acad. Sci. USA 2008, 105, 16731-16736. [CrossRef] [PubMed]

162. Qiu, X.; Zhang, M.; Yang, X.; Hong, N.; Yu, C. Faecalibacterium prausnitzii upregulates regulatory T cells and anti-inflammatory cytokines in treating TNBS-induced colitis. J. Crohn's Colitis 2013, 7, e558-e568. [CrossRef] 
163. Martin, R.; Chain, F.; Miquel, S.; Lu, J.; Gratadoux, J.-J.; Sokol, H.; Verdu, E.F.; Bercik, P.; Humaran, L.G.B.; Langella, P. The Commensal Bacterium Faecalibacterium prausnitzii Is Protective in DNBS-induced Chronic Moderate and Severe Colitis Models. Inflamm. Bowel Dis. 2014, 20, 417-430. [CrossRef]

164. Martín, R.; Miquel, S.; Chain, F.; Natividad, J.M.; Jury, J.; Lu, J.; Sokol, H.; Theodorou, V.; Bercik, P.; Verdu, E.F.; et al. Faecalibacterium prausnitzii prevents physiological damages in a chronic low-grade inflammation murine model. BMC Microbiol. 2015, 15, 67. [CrossRef]

165. Miquel, S.; Leclerc, M.; Martin, R.; Chain, F.; Lenoir, M.; Raguideau, S.; Hudault, S.; Bridonneau, C.; Northen, T.; Bowen, B.; et al. Identification of Metabolic Signatures Linked to Anti-Inflammatory Effects of Faecalibacterium prausnitzii. $m B$ io 2015, 6, e00300-15. [CrossRef] [PubMed]

166. Quevrain, E.; Maubert, M.A.; Michon, C.; Chain, F.; Marquant, R.; Tailhades, J.; Miquel, S.; Carlier, L.; Bermúdez-Humarán, L.G.; Pigneur, B.; et al. Identification of an anti-inflammatory protein from Faecalibacterium prausnitzii, a commensal bacterium deficient in Crohn's disease. Gut 2016, 65, 415-425. [CrossRef]

167. Xu, J.; Liang, R.; Zhang, W.; Tian, K.; Li, J.; Chen, X.; Yu, T.; Chen, Q. Faecalibacterium prausnitzii-derived microbial antiinflammatory molecule regulates intestinal integrity in diabetes mellitus mice via modulating tight junction protein expression. $J$. Diabetes 2020, 12, 224-236. [CrossRef]

168. Vrieze, A.; Van Nood, E.; Holleman, F.; Salojärvi, J.; Kootte, R.S.; Bartelsman, J.F.; Dallinga-Thie, G.M.; Ackermans, M.T.; Serlie, M.J.; Oozeer, R.; et al. Transfer of Intestinal Microbiota From Lean Donors Increases Insulin Sensitivity in Individuals With Metabolic Syndrome. Gastroenterology 2012, 143, 913-916.e7. [CrossRef]

169. Belzer, C.; Chia, L.W.; Aalvink, S.; Chamlagain, B.; Piironen, V.; Knol, J.; de Vos, W.M. Microbial Metabolic Networks at the Mucus Layer Lead to Diet-Independent Butyrate and Vitamin B 12 Production by Intestinal Symbionts. mBio 2017, 8, e00770-17. [CrossRef]

170. Lee, H.; Ko, G. Effect of Metformin on Metabolic Improvement and Gut Microbiota. Appl. Environ. Microbiol. 2014, 80, 5935-5943. [CrossRef]

171. Shin, N.R.; Lee, J.C.; Lee, H.Y.; Kim, M.S.; Whon, T.W.; Lee, M.S.; Bae, J.W. An increase in the Akkermansia spp. population induced by metformin treatment improves glucose homeostasis in diet-induced obese mice. Gut 2014, 63, 727-735. [CrossRef]

172. Derrien, M.; Van Baarlen, P.; Hooiveld, G.; Norin, E.; Müller, M.; de Vos, W.M. Modulation of Mucosal Immune Response, Tolerance, and Proliferation in Mice Colonized by the Mucin-Degrader Akkermansia muciniphila. Front. Microbiol. 2011, 2, 166. [CrossRef]

173. Lukovac, S.; Belzer, C.; Pellis, L.; Keijser, B.J.; de Vos, W.M.; Montijn, R.C.; Roeselers, G. Differential Modulation by Akkermansia muciniphila and Faecalibacterium prausnitzii of Host Peripheral Lipid Metabolism and Histone Acetylation in Mouse Gut Organoids. mBio 2014, 5, e01438-14. [CrossRef]

174. Peter, P.; Lipska, K. The rising cost of diabetes care in the USA. Lancet Diabetes Endocrinol. 2016, 4, 479-480. [CrossRef]

175. Bressa, C.; Bailen, M.; Pérez-Santiago, J.; Gonzalez-Soltero, R.; Pérez, M.; Montalvo-Lominchar, M.G.; Maté-Muñoz, J.L.; Domínguez, R.; Moreno, D.; Larrosa, M. Differences in gut microbiota profile between women with active lifestyle and sedentary women. PLoS ONE 2017, 12, e0171352. [CrossRef]

176. Pascale, A.; Marchesi, N.; Marelli, C.; Coppola, A.; Luzi, L.; Govoni, S.; Giustina, A.; Gazzaruso, C. Microbiota and metabolic diseases. Endocrine 2018, 61, 357-371. [CrossRef]

177. Lau, L.H.S.; Wong, S.H. Microbiota, Obesity and NAFLD. Adv. Exp. Med. Biol. 2018, 1061, 111-125. [CrossRef] [PubMed]

178. Cotillard, A.; Kennedy, S.P.; Kong, L.C.; Prifti, E.; Pons, N.; Le Chatelier, E.; Almeida, M.; Quinquis, B.; Levenez, F.; Galleron, N.; et al. Dietary intervention impact on gut microbial gene richness. Nature 2013, 500, 585-588. [CrossRef] [PubMed]

179. Bouter, K.E.; van Raalte, D.H.; Groen, A.K.; Nieuwdorp, M. Role of the Gut Microbiome in the Pathogenesis of Obesity and Obesity-Related Metabolic Dysfunction. Gastroenterology 2017, 152, 1671-1678. [CrossRef] [PubMed]

180. Hartstra, A.V.; Bouter, K.E.; Bäckhed, F.; Nieuwdorp, M. Insights into the Role of the Microbiome in Obesity and Type 2 Diabetes. Diabetes Care 2014, 38, 159-165. [CrossRef] [PubMed]

181. Kim, M.-S.; Hwang, S.-S.; Park, E.-J.; Bae, J.-W. Strict vegetarian diet improves the risk factors associated with metabolic diseases by modulating gut microbiota and reducing intestinal inflammation. Environ. Microbiol. Rep. 2013, 5, 765-775. [CrossRef]

182. Vallianou, N.; Stratigou, T.; Christodoulatos, G.S.; Dalamaga, M. Understanding the Role of the Gut Microbiome and Microbial Metabolites in Obesity and Obesity-Associated Metabolic Disorders: Current Evidence and Perspectives. Curr. Obes. Rep. 2019, 8 , 317-332. [CrossRef]

183. Cani, P.D.; Lecourt, E.; Dewulf, E.M.; Sohet, F.M.; Pachikian, B.D.; Naslain, D.; De Backer, F.; Neyrinck, A.; Delzenne, N. Gut microbiota fermentation of prebiotics increases satietogenic and incretin gut peptide production with consequences for appetite sensation and glucose response after a meal. Am. J. Clin. Nutr. 2009, 90, 1236-1243. [CrossRef]

184. Liu, F.; Prabhakar, M.; Ju, J.; Long, H.; Zhou, H.-W. Effect of inulin-type fructans on blood lipid profile and glucose level: A systematic review and meta-analysis of randomized controlled trials. Eur. J. Clin. Nutr. 2016, 71, 9-20. [CrossRef] [PubMed]

185. Lu, Z.X.; Walker, K.Z.; Muir, J.G.; Mascara, T.; O'Dea, K. Arabinoxylan fiber, a byproduct of wheat flour processing, reduces the postprandial glucose response in normoglycemic subjects. Am. J. Clin. Nutr. 2000, 71, 1123-1128. [CrossRef] [PubMed]

186. Simon, M.-C.; Strassburger, K.; Nowotny, B.; Kolb, H.; Nowotny, P.; Burkart, V.; Zivehe, F.; Hwang, J.-H.; Stehle, P.; Pacini, G.; et al Intake ofLactobacillus reuteriImproves Incretin and Insulin Secretion in Glucose-Tolerant Humans: A Proof of Concept. Diabetes Care 2015, 38, 1827-1834. [CrossRef] 
187. Uusitalo, U.; Liu, X.; Yang, J.; Aronsson, C.A.; Hummel, S.; Butterworth, M.; Lernmark, Å.; Rewers, M.; Hagopian, W.; She, J.-X.; et al. Association of Early Exposure of Probiotics and Islet Autoimmunity in the TEDDY Study. JAMA Pediatr. 2016, 170, 20-28. [CrossRef]

188. Rezazadeh, L.; Alipour, B.; Jafarabadi, M.A.; Behrooz, M.; Gargari, B.P. Daily consumption effects of probiotic yogurt containing Lactobacillus acidophilus La5 and Bifidobacterium lactis Bb12 on oxidative stress in metabolic syndrome patients. Clin. Nutr. ESPEN 2021, 41, 136-142. [CrossRef]

189. Kooshki, A.A.; Tofighiyan, T.; Rakhshani, M.H. Effects of Synbiotics on Inflammatory Markers in Patients with Type 2 Diabetes Mellitus. Glob. J. Health Sci. 2015, 7, 1-5. [CrossRef]

190. Mahboobi, S.; Rahimi, F.; Jafarnejad, S. Effects of Prebiotic and Synbiotic Supplementation on Glycaemia and Lipid Profile in Type 2 Diabetes: A Meta-Analysis of Randomized Controlled Trials. Adv. Pharm. Bull. 2018, 8, 565-574. [CrossRef]

191. Ferrarese, R.; Ceresola, E.R.; Preti, A.; Canducci, F. Probiotics, prebiotics and synbiotics for weight loss and metabolic syndrome in the microbiome era. Eur. Rev. Med. Pharmacol. Sci. 2018, 22, 7588-7605.

192. Marietta, E.V.; Gomez, A.M.; Yeoman, C.; Tilahun, A.Y.; Clark, C.R.; Luckey, D.H.; Murray, J.A.; White, B.A.; Kudva, Y.C.; Rajagopalan, G. Low Incidence of Spontaneous Type 1 Diabetes in Non-Obese Diabetic Mice Raised on Gluten-Free Diets Is Associated with Changes in the Intestinal Microbiome. PLOS ONE 2013, 8, e78687. [CrossRef]

193. Hummel, S.; Pflüger, M.; Hummel, M.; Bonifacio, E.; Ziegler, A.-G. Primary Dietary Intervention Study to Reduce the Risk of Islet Autoimmunity in Children at Increased Risk for Type 1 Diabetes: The BABYDIET study. Diabetes Care 2011, 34, 1301-1305. [CrossRef]

194. Beyerlein, A.; Chmiel, R.; Hummel, S.; Winkler, C.; Bonifacio, E.; Ziegler, A.-G. Timing of Gluten Introduction and Islet Autoimmunity in Young Children: Updated Results From the BABYDIET Study. Diabetes Care 2014, 37, e194-e195. [CrossRef]

195. Scott, F.W.; Rowsell, P.; Wang, G.-S.; Burghardt, K.; Kolb, H.; Flohé, S. Oral exposure to diabetes-promoting food or immunomodulators in neonates alters gut cytokines and diabetes. Diabetes 2002, 51, 73-78. [CrossRef]

196. Cani, P.D.; Neyrinck, A.; Fava, F.; Knauf, C.; Burcelin, R.G.; Tuohy, K.; Gibson, G.R.; Delzenne, N.M. Selective increases of bifidobacteria in gut microflora improve high-fat-diet-induced diabetes in mice through a mechanism associated with endotoxaemia. Diabetologia 2007, 50, 2374-2383. [CrossRef]

197. Tian, Y.; Nichols, R.; Cai, J.; Patterson, A.; Cantorna, M.T. Vitamin A deficiency in mice alters host and gut microbial metabolism leading to altered energy homeostasis. J. Nutr. Biochem. 2018, 54, 28-34. [CrossRef]

198. Mucida, D.; Park, Y.; Kim, G.; Turovskaya, O.; Scott, I.; Kronenberg, M.; Cheroutre, H. Reciprocal T H 17 and Regulatory T Cell Differentiation Mediated by Retinoic Acid. Science 2007, 317, 256-260. [CrossRef]

199. Xia, T.; Lai, W.; Han, M.; Han, M.; Ma, X.; Zhang, L. Dietary ZnO nanoparticles alters intestinal microbiota and inflammation response in weaned piglets. Oncotarget 2017, 8, 64878-64891. [CrossRef]

200. De Groot, P.; Nikolic, T.; Pellegrini, S.; Sordi, V.; Imangaliyev, S.; Rampanelli, E.; Hanssen, N.; Attaye, I.; Bakker, G.; Duinkerken, G.; et al. Faecal microbiota transplantation halts progression of human new-onset type 1 diabetes in a randomised controlled trial. Gut 2021, 70, 92-105. [CrossRef]

201. Peng, J.; Narasimhan, S.; Marchesi, J.R.; Benson, A.; Wong, F.S.; Wen, L. Long term effect of gut microbiota transfer on diabetes development. J. Autoimmun. 2014, 53, 85-94. [CrossRef] [PubMed] 